\title{
Geological Heritage, Geotourism and Local Development in Aggtelek National Park (NE Hungary)
}

\author{
Tamás Telbisz $^{1}$ (D) $\cdot$ Péter Gruber ${ }^{2} \cdot$ László Mari $^{1} \cdot$ Margit Kőszegi $^{3} \cdot$ Zsolt Bottlik $^{3} \cdot$ Tibor Standovár $^{4}$
}

Received: 6 April 2019 / Accepted: 7 January 2020 / Published online: 25 January 2020

(C) The Author(s) 2020

\begin{abstract}
We examine how geoconservation and geotourism can help the local development of an economically underdeveloped karst area. First, we briefly present the geoheritage of Aggtelek National Park, which largely overlaps the area of the Aggtelek Karst. The area is built up predominantly of Triassic limestones and dolomites. It is a typical temperate zone, medium mountain karst area with doline-dotted karst plateaus and tectonic-fluvial valleys. Besides caves, the past history of iron mining also enriches its geoheritage. Aggtelek National Park was set aside in 1985. The caves of Aggtelek Karst and Slovak Karst became part of the UNESCO World Heritage in 1995 due to the high diversity of cave types and morphology. Socially, the area of the national park is a disadvantaged border region in NE Hungary. Baradla Cave has always been a popular tourist destination, but visitor numbers fell significantly after 1985. Tourism is largely focused on Baradla Cave, and thus it can be considered "sensu lato" geotourism. Reasons for the changes in visitor numbers are discussed in this paper. Tourist motivations, the significance of geotourism and other tourism-related issues were explored in our study by questionnaire surveys and semi-structured interviews. Furthermore, the balance of geoconservation versus bioconservation is also examined. Finally, the relationship of geotourism, nature protection and local development is discussed. We conclude that the socio-economic situation of the Aggtelek Karst microregion is relatively better than that of the neighbouring regions, and this relative welfare is due to the existence of the national park and Baradla Cave.
\end{abstract}

Keywords Aggtelek Karst · National park · Baradla cave $\cdot$ Geotourism $\cdot$ Rural development

\section{Introduction}

Tourism is one of the most quickly growing sectors in the world economy (UNWTO 2019). Within this sector, the proportion of nature-based tourism is also growing (Kuenzi and

This article is part of the Topical Collection on Geoheritage and Conservation: Modern Approaches and Applications Towards the 2030 Agenda, IX ProGEO Symposium, Poland, 25-28th June, 2018

Tamás Telbisz

telbisztom@caesar.elte.hu

1 Department of Physical Geography, Eötvös Loránd University, Pázmány Péter 1/C, Budapest 1117, Hungary

2 Aggtelek National Park, Tengerszem oldal 1, Jósvafö, Hungary

3 Department of Regional Science, Eötvös Loránd University, Pázmány Péter 1/C, Budapest 1117, Hungary

4 Department of Plant Taxonomy and Ecology, Eötvös Loránd University, Pázmány Péter 1/C, Budapest 1117, Hungary
McNeely 2008; Liu et al. 2016), and geotourism as a branch of nature-based tourism is also becoming more and more important (Dowling and Newsome 2006; Dowling 2011). Tourism to national parks is on a rising trend at the global level (Balmford et al. 2009; Stemberk et al. 2018), although the scenarios vary over time and space. For example, total visitor numbers at national parks in the USA moved on a remarkable upward trend from 1945 to 1987 , followed by stagnation with some fluctuations until 2013 and then a sharp increase again after that (NPS 2019). In Hungary, the total number of registered national park visitors rose from 0.9 million to 1.6 million in the period 2005 to 2017 (Pádárné Török 2018). We would note here that only tourists who visit ecotourism facilities such as visitor centres or caves are registered in Hungary. Five Hungarian national parks (Balaton-felvidéki, Bükk, DunaIpoly, Körös-Maros, Hortobágy) saw significant increases in visitor numbers during that period, while five other national parks (Aggtelek, Duna-Dráva, Fertő-Hanság, Kiskunság, Örség), including Aggtelek National Park presented in this paper, experienced only a slight increase with occasional 
declines (Pádárné Török 2018). Various factors can affect visitor numbers, including the economic crisis in general, higher fuel prices (Stevens et al. 2014), visitor opinions, government policies and national park characteristics (Stemberk et al. 2018).

The values and philosophy of national parks have undergone several modifications over the last century and a half (Frost and Hall 2009). In the early days, conserving pristine nature was the main goal, but the exploitation of tourism potential was also a significant aspect. The preservation of wildlife was added to the goals in the second step, especially when national parks were established on large African territories. The principles of ecological integrity and biodiversity were only formulated after World War II. The preservation of cultural landscapes and historical heritage, as well as the promotion of scientific research and education, were also mainly added to the objectives after World War II. Today, it is often experienced that bioconservation is more pronounced and receives significantly higher financial support than geoconservation (Brilha 2002; Crofts 2018; Gordon et al. 2018; Stepišnik and Trenchovska 2018). Protected areas including national parks are often located in relatively sparsely populated and less developed areas, and it is common that they are situated along national borders (Butler and Boyd 2000; Mose 2007; Frost and Hall 2009). As a result of this, it has been possible to better preserve the natural environment in these circumstances. Consequently, the idea that nature protection in otherwise disadvantaged areas should contribute to local development logically came into light (Mose 2007). Municipalities located in national parks have a higher income than those located elsewhere (Stemberk et al. 2018). This idea can be valid also for places where geoconservation is in the focus (Ateș and Ateș 2019). Former mining areas are typical for this situation as they are significant from a geoconservation point of view and at the same time they are socially depressed zones (Evans 2005). Recently, geoparks have become the flagships of geoconservation, and sustainable development is one of the main aims of geoparks (Zouros and McKeever 2004; McKeever and Zouros 2005; Farsani et al. 2011; Lazzari and Aloia 2014; Han et al. 2018). In many cases, karst terrains are economically underdeveloped areas (Telbisz et al. 2014, 2015, 2016a, 2019), but they have varied attractions from the perspective of geotourism (Dowling and Newsome 2006). As Cigna and Forti (2013) stated, caves are the most important geotouristic features in the world.

In this paper, we examine Aggtelek National Park (ANP, Hungary), which was established on a well-known karst terrain, situated in a socially depressed area. Our first aim is to briefly present the geological heritage of ANP. Second, we aim to explain the changes in visitor numbers and understand tourist motivations and attitudes using statistical data, tourist questionnaires and interviews with managers and local stakeholders. We also intend to estimate the proportion of pure geotourists and general geotourists (in the meaning of Božić and Tomic 2015). Third, our goal is to examine the relationship of bioconservation (biological research) and geoconservation (earth science research) in the case of ANP. Finally, our most important aim is to demonstrate that geotourism and nature protection may have a significant impact on local socio-economic development.

\section{Location of the Study Area}

ANP lies in NE Hungary (Fig. 1) at the border between Hungary and Slovakia. ANP was set aside in 1985 to protect the karst terrain and its caves. The northern border of ANP coincides with the national border, and on the other side, in Slovakia, there is also a national park, the "Slovak Karst National Park". The area of ANP largely overlaps the area of Aggtelek Karst. Historically, Aggtelek Karst (in Hungarian: Aggteleki-karszt) and Slovak Karst (in Slovakian: Slovenský kras) are hilly and middle mountainous areas, which belong to Gömör-Torna/Gemer-Turňa Karst. Altogether, they are parts of the Inner West Carpathians (Less 2000).

\section{Geological and Geomorphological Settings}

Aggtelek Karst is mostly famous for its caves, especially Baradla Cave, which is often called as "Aggtelek Dripstone Cave" in Hungarian popular literature, as it is located next to Aggtelek village. As Baradla Cave always had an open, visible entry, it has been known and used since prehistorical times. On the other hand, Domica Cave in Slovakia was explored in 1926 and the connection between these two caves was explored in 1932, so since that time, we can speak about the Baradla-Domica cave system. Besides this cave system, there are many other caves with varied types, morphology and depositions.

Aggtelek Karst is one of Hungary's geologically most diverse areas despite its relatively small size, considering both stratigraphy and tectonics (Less 2000). From a geotectonic viewpoint, the local Silicicum-Aggtelek and Meliata units are parts of the Inner West Carpathians and belong to the Adria-derived nappes and Meliata Ocean remnants of the ALCAPA Mega-Unit (Schmid et al. 2008). Aggtelek Karst is built up mainly of Late Permian to Jurassic sedimentary nappe stacks (Kövér et al. 2009), in which Triassic carbonate rocks are the most important (Fig. 2). These rocks were deposited on the carbonate platforms of the Neotethys Ocean. The most widely distributed formation is the Upper Triassic Wetterstein Formation, which consists of well karstifiable limestones, and to a lesser extent, of less karstifiable dolomites (Less 2000). Furthermore, Gutenstein, Steinalm, Halstatt, Dachstein and Pötschen Limestones also occur in the area. In the Jurassic, the ocean became deeper, and thus carbonate deposition was halted. At the end of this period, the 


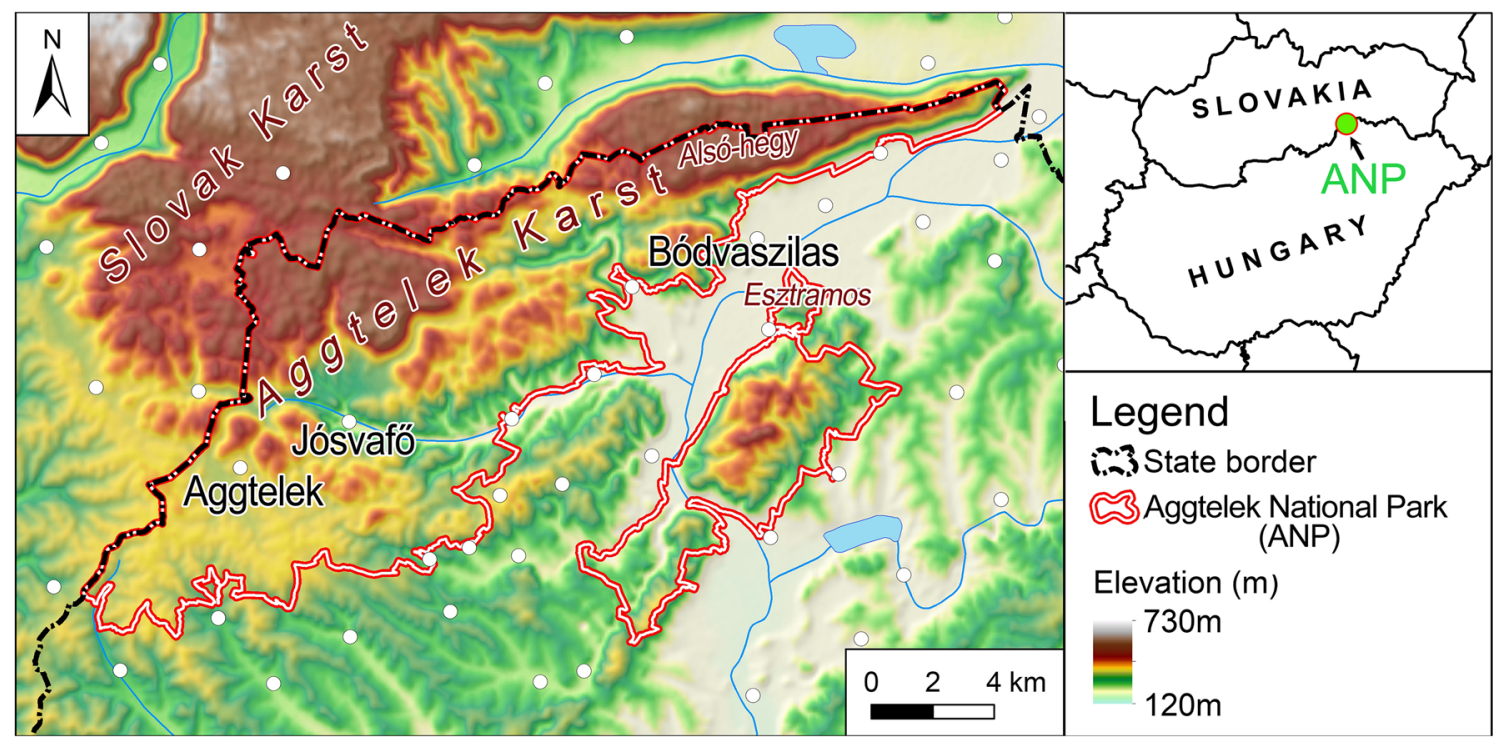

Fig. 1 Location of Aggtelek National Park

subduction of the oceanic crust took place, but a smaller part of the oceanic crust was obducted on the continental crust, and therefore some pieces of the former oceanic crust can be found on the surface near Meliata (in Slovakia; Gaál and Bella 2005). As the northern part of the area was slightly uplifted, the Triassic carbonate sediments slid towards the south on the plastic Permian evaporites, and nappe stacks were formed. In the Cretaceous, the north-south compression resulted in folding structures, and a second generation of nappes was created (Less 2000). The third important tectonic phase affected the area in the Oligocene, when mainly horizontal deformations occurred. The previous tectonic boundaries were revived, and traces of these horizontal faults can be still recognized in the present topography as W-E oriented valleys. In the Miocene, most of present-day Hungary was flooded by the Pannonian Sea, which later gradually decreased in size and became a lake. The lake penetrated into the lower terrains of the carbonate area, and lacustrine sediments were deposited (Less 2000). Karstification began in the area in the second part of the Miocene period with a subtropical climate and at a relatively low elevation (Zámbó 1998). Finally, the area north of the karst terrain started to uplift in the Pliocene, and the whole karst area had a large-scale, north-south sloping surface, which is a dominant characteristic of the present-day topography (Gyuricza and Sásdi 2009; Telbisz 2011). The rivers flowing southwards from the northern mountains created a pediplain and covered the area with fluvial sediments (gravels), but later on - due to the uneven uplift of tectonic

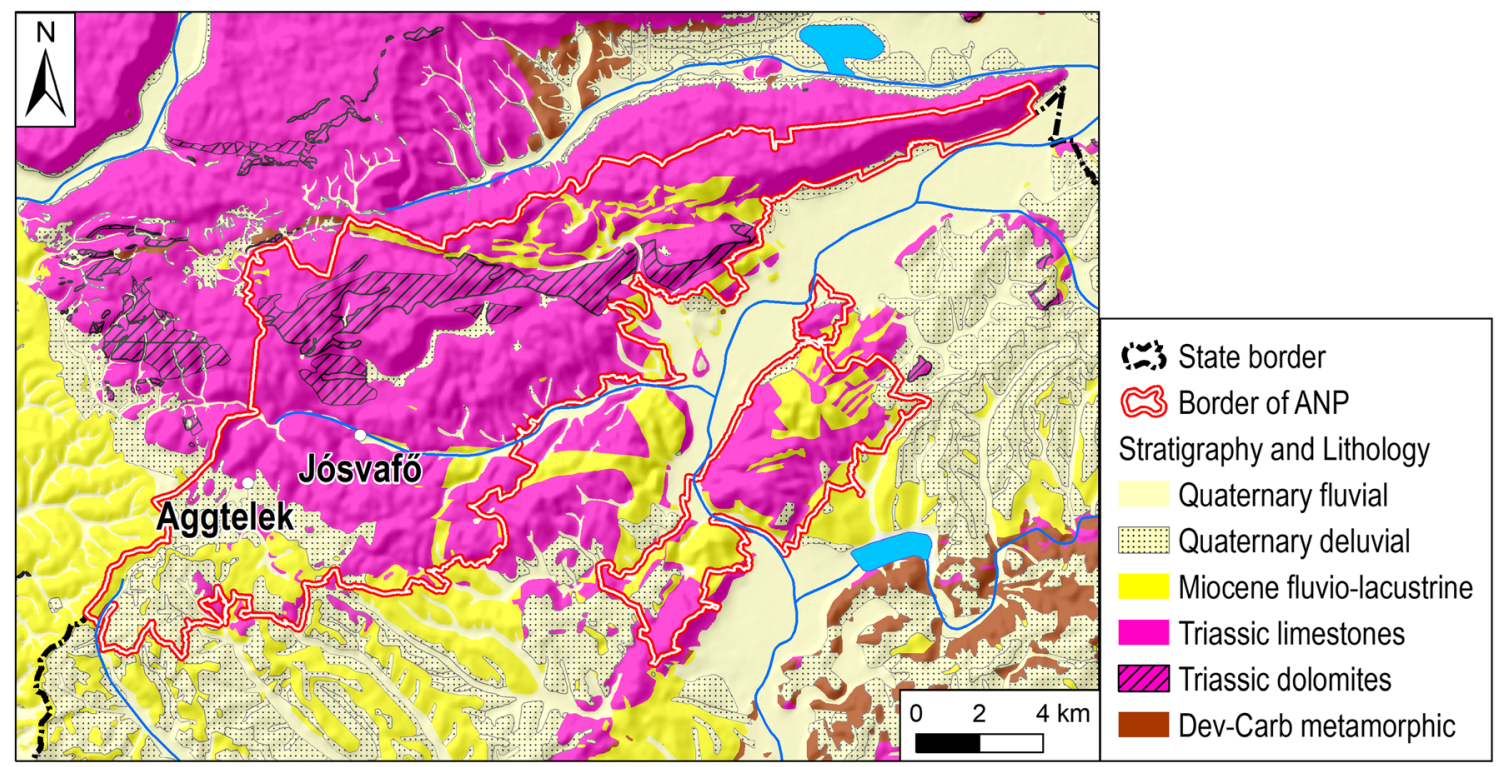

Fig. 2 Geological map of the Aggtelek Karst. Dev-Carb: Devonian-Carboniferous. ANP: Aggtelek National Park 
blocks - the uplifted segments became karst plateaus from which the fluvial deposits were gradually eroded, and between them, valleys (gorges or wider, gentler valleys) were formed, and karst processes gained dominance (Zámbó 1998; Móga 1999; Telbisz 2011).

As a result of these tectonic processes, the Aggtelek Karst is characterized by 350 to $600 \mathrm{~m}$ a.s.l. high flat summits and small area plateaus, whereas the plateaus of the northern Slovak Karst are larger and higher. The mosaic-like topography and the rivers (streams) flowing from the northern mountains made karst development highly diverse. Plateaus are mostly dotted by solution dolines with different densities (130 dolines $/ \mathrm{km}^{2}$; Telbisz et al. 2016b). Dolines are typically arranged into rows along dry valleys. The genesis of valleys can be explained partly by tectonic reasons and partly by the earlier drainage network (Zámbó 1998; Telbisz 2011). The valleys of the plateaus are dry, whereas the valleys between the plateaus have active streams or rivers. Plateaus are covered by soil and vegetation, and thus bare karren are rare, and rounded subsoil karren are typical, but on steep plateau slopes, especially with S-SW exposition, some spectacular karrenfields were formed partly due to human impact (Zámbó 1998). At the bottom of the karst plateaus, along the contact of karst and non-karst areas stream sinks or springs are found depending on the topographic situation. Naturally, the karst area is poor in lakes, but in some plugged stream sinks or dolines, small lakes can be found (e.g. Red Lake between Aggtelek and Jósvafö villages).

\section{Methods}

Several types of data have been used in our analysis. First, we acquired statistical data to briefly present the demographic and social situation of the Aggtelek microregion. Second, we examined the changes in visitor numbers at Baradla Cave. Visitor statistics are available for a period of more than 100 years. Third, we conducted semi-structured interviews with ANP managers, mayors of the neighbouring settlements and external experts, who performed research within ANP or know the area as nature protection officials. Finally, a questionnaire survey was performed with locals and tourists. Due to space limitations, the questionnaires with locals are not evaluated in this paper. A questionnaire survey is a widely applied method to examine visitors' perceptions, characteristics, motivations and attitudes about development priorities. For example, surveys have been used in relation to Natura 2000 protected areas (Pietrzyk-Kaszyńska et al. 2012), national parks (Trakolis 2001; Papageorgiou and Kassioumis 2005), geosites (Zgłobicki and Baran-Zgłobicka 2013; Štrba 2019) and caves (Kim et al. 2008). In our survey, we used two, A4sized forms with 26 , mostly closed-ended questions ranging from basic demographic data through the mode and motivation of tourism to some potential development-related questions. In order to obtain some information about foreign tourists as well, the forms were also created in English and Slovakian with some minor adaptations. The semi-structured interviews were carried out in several phases in 2018, whereas most of the questionnaires were completed by tourists in July 2018. The location of the mass survey was basically near Baradla Cave entrances (in Aggtelek and Jósvafö, Fig. 1), but a smaller proportion of questionnaires were completed at other settlements. The tourists could fill out the forms by themselves or with the help of assistants.

In connection with the relative importance of geological versus biological values, we performed a bibliographic analysis. We searched publications related to the word "Aggtelek" in the largest Hungarian journal database (https://matarka.hu/) and in Scopus (https://www.scopus.com) and analysed the thematic distribution and temporal changes of these publications.

\section{Geological Heritage of Aggtelek National Park}

A complete geosite inventory has not yet been undertaken in Aggtelek National Park. However, we briefly list here the elements of the local geoheritage. Caves are clearly the most significant elements, but exokarst landforms and geological type sections are also abundant. There are 24 geological type sections at the Aggtelek Karst (representing mostly Triassic formations), and one unique feature is that seven protected type sections are found underground, in Baradla Cave. In addition, mining history makes the local geo-image even more colourful.

\section{Caves of the Area}

There are around 1200 caves in the $200 \mathrm{~km}^{2}$ area of ANP. Caves formed by meteoric waters are the most abundant, including inflow caves, outflow caves and through caves. Branchwork caves (Palmer 1991) are the most common type. They are generally rich in different types of speleothems. In addition to the most common speleothems such as soda straws, stalactites and stalagmites, one can also find helictites, coralloids and bulbous forms (Fig. 3). Some plateaus (e.g. Alsó Hill) are extremely rich in shaft caves (known locally as "zsomboly") due to the nearly vertical, well karstifiable limestone beds. Vecsembükki-zsomboly is a typical example and is the third deepest cave in Hungary (236 m depth).

In the eastern part of the karst, in Esztramos Hill, thermal caves are also found (e.g. Rákóczi Cave). The passage pattern and deposition forms of these caves are entirely different from those previously discussed (Takácsné Bolner 1998). These caves were first explored by iron and rock mining because they did not have natural entrances at that time. Mining ceased in the area in 1996, but there are still many former mining 


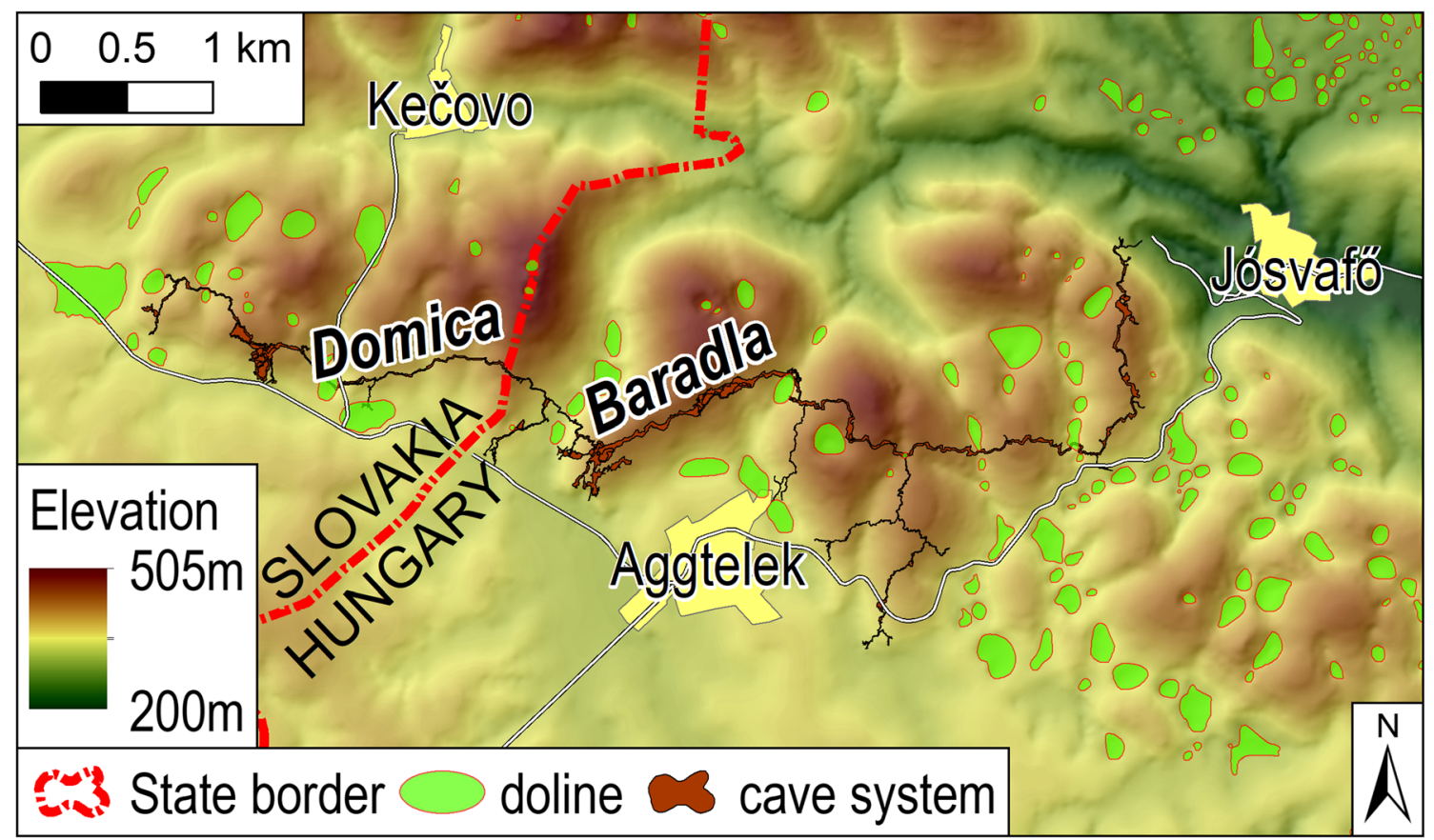

Fig. 3 Plan view of the Baradla-Domica cave system with topography and dolines

passages in the hill, and they are now under restoration to make them usable for a modern, experience-focused mining museum.

In other parts of the karst, some caves with natural entrances have long been known, but many new caves were discovered in the decades after World War II, when systematic investigation and scientific methods such as water tracing were applied. Béke Cave, Meteor Cave, Kossuth Cave or Szabadság Cave can be mentioned as the most important post-war discoveries.

\section{The Baradla-Domica Cave System}

The longest ( $25.5 \mathrm{~km}$ long) and most diverse cave in the area is the Baradla-Domica cave system (Gruber and Gaál 2014; Fig. 4). According to Ford and Williams (1989), it is a typical example of multi-storey through caves. On the Hungarian side, small streams flowing on covered karst terrain reach the karst contact and sink into Baradla Cave. The natural entrance of the cave is found at the edge of Aggtelek village. Due to the openness of the cave, it was inhabited in prehistorical times. The oldest undisputed findings are from the Neolithic Period, when the so-called "Bükk Culture" people settled in the cave around 5000 BC (Székely 1998; Holl 2007). In addition to artefacts (ceramics, bone and stone tools), these people left a special print in the cave, as many dripstones were coloured to grey or black from the torches and fires they used. However, when they left the cave, it remained uninhabited for several millennia and thus younger speleothem layers coated these dark layers (Gradziński et al. 2007).
The main branch of the cave is spacious and has many large rooms; it is roughly horizontal, which makes walking easy. It is also rich in speleothems and thus everything is in place for an ideal show cave. Scientific exploration of the cave began at the end of the eighteenth century. The first map of the thenknown cave was drawn in 1794 based on a careful survey, and is thus thought to be the first engineering cave map in the world (Szvoboda 1998). Scientific research has continued since then, at varying intensities. Present-day investigations focus on cave genesis theories (Gyuricza and Sásdi 2009; Veress and Unger 2015; Bosák et al. 2004; Bella et al. 2019), hydrogeologic studies (Borbás et al. 2011; Gruber et al. 2012), exploration for new passages at the lower, inundated levels, speleobiology and speleothems (Zámbó et al. 2002; Galbács et al. 2011; Czuppon et al. 2018). Today, cave depositions are studied principally because of their palaeoclimatic significance (Demény et al. 2017). The outflow of the cave is found at the end of the 7-km long main branch near Jósvafö village, but the terminal passages are narrow and partly inundated, so there was no natural entrance to the cave from this side. However, in order to reach the inner cave passages from that side, an artificial tunnel was created near Jósvafö village and another one about midway between Aggtelek and Jósvafó villages (next to Red Lake).

On the Slovakian side, the Domica Cave is another story. In historical times it had no natural entrance, and thus it remained unknown until 1926. However, explorers soon realized that Neolithic people had inhabited this cave. Consequently, it must have had a natural entrance that time, but it was closed naturally after the Neolithic Period (Gruber and Gaál 2014). 


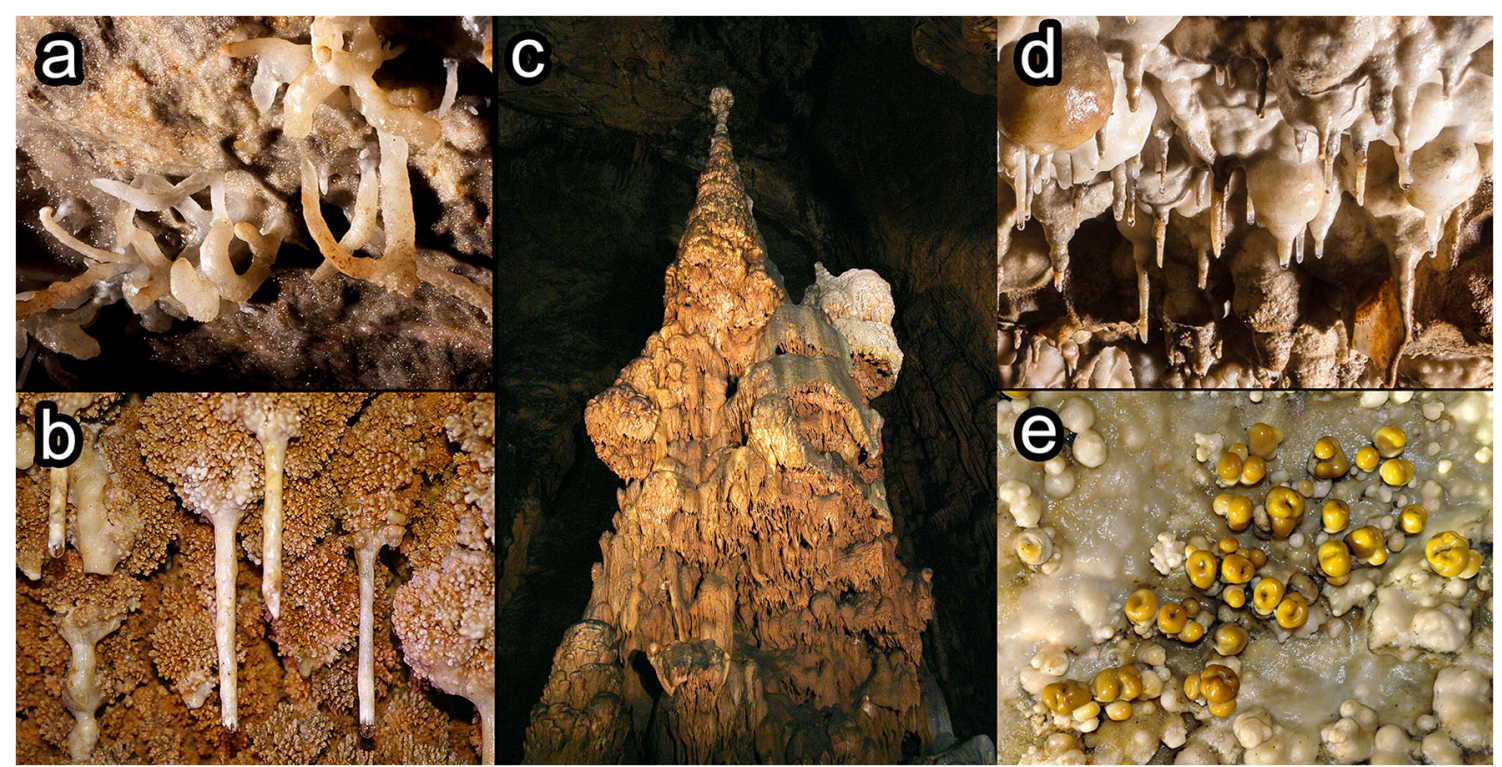

Fig. 4 Speleothems from the Aggtelek Karst caves: a helictites from Meteor Cave; b coralloids with soda straw from Rákóczi Cave; $\mathbf{c}$ the largest stalagmite of Hungary in Baradla Cave ("Observatory", 19 m); d

The connection between Domica and Baradla is a very narrow, stream passage because there are some less soluble beds in-between the well karstifiable limestone layers. Previously, this passage was entirely flooded and was hard to get through. This section was first explored from the Hungarian side in 1932. One peculiar feature of the Baradla-Domica cave system is that the state border can be crossed below the surface. In the twentieth century, this crossing was closed with an iron gate for political reasons. Since 2007, it is free to move from one country to the other, but the narrow, flooded section in the Hungarian side is passable only by cavers. The state border can be relatively easily reached from the Domica side.

\section{Exokarst Landforms as Potential Geosites}

First, we mention the karren as the smallest karst features. The karrenfield formed at the edge of Aggtelek village on the hillslope of Tó-hegy is the most spectacular form of its kind, where bare and soil-covered karren can be seen. In addition, Aggtelek Lake, a plugged former stream sink is also found at the foot of this hillslope. A further advantage of this site from a geotouristic viewpoint is its proximity to the main tourist centre of Aggtelek.

Sinkholes are abundant throughout the area, as there are ca. 1100 dolines in Aggtelek National Park (Telbisz 2001). Stream sinks are also numerous: typical examples are the Zombor-lyuk, Nagy-Ravasz-lyuk and Kis-Ravasz-lyuk near Aggtelek village, which drain water to Baradla Cave, but many other good examples could be mentioned. As for larger landforms, we can mention the Jósvafö-fennsík (plateau), a large doline-dotted, slightly uplifted depression surrounded by higher plateaus. It is considered to be a paleo-polje and is bulbous stalactites from Baradla Cave; e popcorn speleothems from Rákóczi Cave. Photographs by Csaba Egri (a, d) and Tamás Telbisz (b, c, e)

a very interesting site from the viewpoint of landform development (Bella et al. 2016).

Finally, springs are also important geosites. They have high discharge fluctuations with occasional floods, and travertine depositions are generally formed in the outflowing streams. These sites are especially suitable for geoeducation purpose because water is one of the most important resource of karst areas. The Jósva springs (flowing from Baradla Cave), the Komlós spring (flowing from Béke Cave) or the Tohonya spring (flowing from Kossuth Cave) are perfect examples, and all of them are found in the vicinity of Jósvafö village.

\section{Nature Protection, Tourism and Social Background of Aggtelek National Park}

\section{Landscape Protection Area, National Park and UNESCO World Heritage Site}

The Baradla Cave was first protected in 1940. Since 1961, all caves in Hungary are protected ex lege, and this also applies to Baradla Cave. In 1978, due to the geological, geomorphological and speleological values, the surface area of the karst became a "landscape protected area", which is a nature protection category in Hungary below the national park level. In 1979, the area became a Biosphere Reserve (Szvoboda 1998). ANP was set aside in 1985. It is very important to mention that it was the first Hungarian national park which was especially created for the protection of a karst terrain i.e. geoconservation was the focus from the beginning. We would also note that Bükk National Park (Hungary) founded in 1977 also has significant karst areas, but it is a more complex landscape, and karst protection was only one of the reasons but not the 
primary aim when that national park was created. In 1995, the caves of Aggtelek Karst and Slovak Karst were inscribed on the UNESCO World Heritage List as a transboundary property, because of the high diversity of temperate karst cave morphology, a fact that also underlines the outstanding geological values in ANP.

\section{Cave Tourism and Tourism Infrastructure in Aggtelek National Park}

Tourism in the Baradla Cave goes back more than 200 years (Gruber and Gaál 2014). In the nineteenth century, it was known as the longest cave in Europe, and thus many Hungarians and foreigners came here to visit including famous poets and powerful people, who are documented in the guest books of the cave. In Hungary, the popular name "Aggtelek Dripstone Cave" is deeply rooted in public awareness, because it is the main example in the schools when caves, speleothems or karst processes are taught. The significance of this fact is also reflected in our survey (see below). Briefly, the Baradla Cave is regarded as a "must see" in the Hungarian context. At present, there are short show cave tours starting from Aggtelek village (1-km length) and from Red Lake to Jósvafó village $(2.3 \mathrm{~km})$, but a long trip along the main branch from Aggtelek to Jósvafó $(6.7 \mathrm{~km})$ is also available for tourists. The Rákóczi Cave at Esztramos Hill is another show cave with several ladders, and the national park also provides adventure cave tours to some other caves (Kossuth Cave, Meteor Cave, Vass Imre Cave, Béke Cave). However, the overwhelming majority of tourists visit only the Aggtelek part of the Baradla Cave.

Tourism facilities are just presented very briefly here. As for surface hikes, there is a well-marked system of hiking paths in the national park. For education purpose, there are ten education trails, concentrated mostly (but not exclusively) around Aggtelek and Jósvafö villages. The education trails have leaflet guides in three languages. However, only three of them can be called geotrails, because the others focus rather on plants, animals and historical heritage. There is one visitor centre at the Vörös-tó (Red Lake) entrance of Baradla Cave, but it does not have a modern exposition and most of the visitors do not come to this site. Another very small museum is found at the Jósvafö entrance of the Baradla Cave, focusing on caving and karst hydrogeology through the life of Hubert Kessler, a famous hydrogeologist, who conducted several explorations and introduced innovations around Aggtelek in the first half of the twentieth century. Furthermore, there are three small education centres maintained by the national park, which provide programmes predominantly for school children.

Accommodation possibilities are limited: there are two small hotels (one in Aggtelek and one in Jósvafö), and there is a tourist hostel with a campground in Aggtelek village.
Visitors staying for several days generally reside in private guesthouses or rooms.

\section{Social Situation of the Aggtelek Karst Microregion Settlements}

As for the microregion, the Aggtelek Karst has always been a sparsely inhabited area due to the relatively harsh natural settings of the karst terrain, and its population stagnated or even slightly decreased during the nineteenth century. In the twentieth century, one can observe a moderate increase until 1970, but since that time there has been a strong downward trend (Telbisz et al. 2015; Fig. 5). The reasons are both natural decrease and emigration, since there is a lack of employment opportunities in the microregion. The border position and the distance from major transport routes further amplifies these trends. There are 21 settlements in the immediate vicinity of the national park, and two villages (Aggtelek and Jósvafö) are directly located in the area of ANP. The largest of these (Bódvaszilas village) has 1101 inhabitants (data from 2011), but most settlements have only around 100 people, and there are some micro-villages with only some tens of inhabitants. Since the political transition in 1990, only three settlements (Szin, Tornanádaska, Szalonna) have increased their populations. This increase is due to the growing proportion of Roma people in these villages as they have a higher birth rate. Aggtelek village has had a stagnating population since 1990, and all other settlements have decreasing populations.

The closest larger city, Miskolc, is located $60 \mathrm{~km}$ from Aggtelek village, which is not such a great distance in many countries, but here, in the karst area, almost everyone feels that Aggtelek is "far from everywhere" and is the "outback" of Hungary.

\section{Results}

\section{Temporal Changes in Cave Tourism}

Since the Baradla Cave has long been the most important tourist destination in the microregion, and practically all tourists arriving here visit the Cave, its visitor numbers well characterize the tourism of the area from the beginning of the twentieth century until now (see Tózsa 1996). Based on these data (Fig. 6), it is stated that the main period of local tourism growth occurred from 1950 to 1975 . This was followed by a 10 -year-long peak, with about 250,000 visitors a year. Thereafter, a decrease took place in several steps. The period of decline started just 3 years after the foundation of the national park. However, the reason of the decline is not the foundation of the national park, but rather the fact that this was the time when Hungarians could get a "world passport" in the final years of the communist regime since 1988. This 
Fig. 5 Demographic changes of Aggtelek Karst microregion. Total population of the microregion is shown on the primary axis (in thousands), whereas the populations of Aggtelek and Jósvafö villages are shown on the secondary axis (in hundreds)

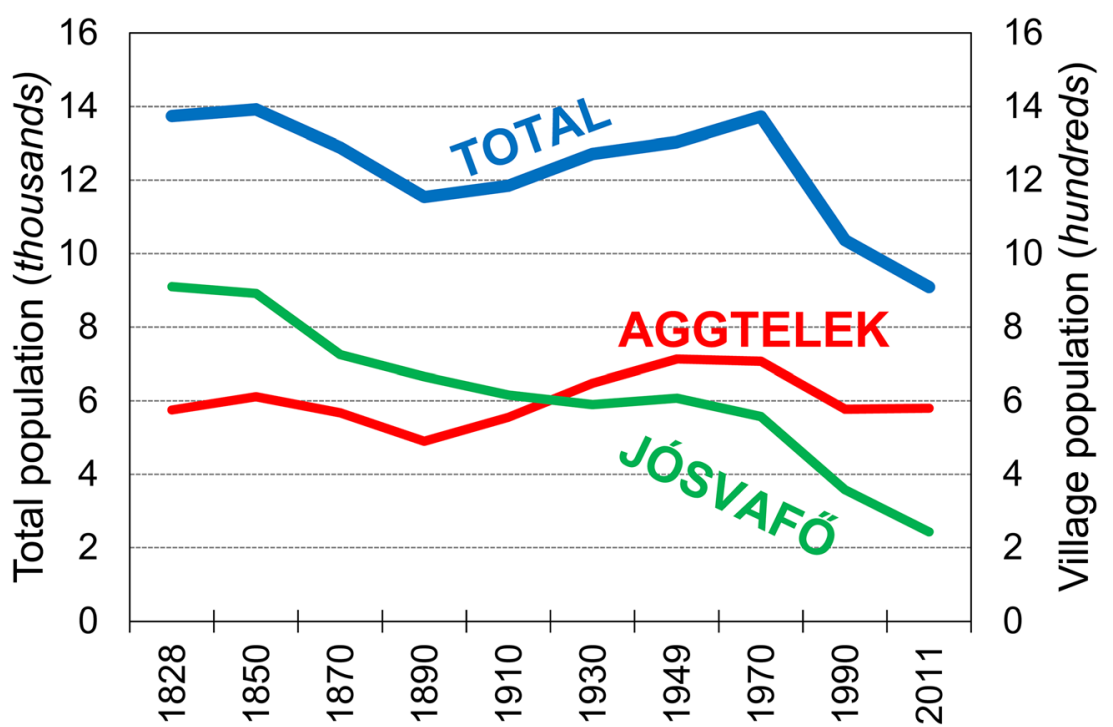

opened the world to them, and Hungarians began to travel to international tourist destinations instead of the traditional domestic locations. The fact remains that the foundation of the national park was not able to prevent the decline in tourism. A decade later, when the caves were recognized as World Heritage, the decline in visitor numbers halted for a while, but it is difficult to judge the role of this title in that process. Furthermore, the decline has continued since the early 2000s. In 2007, Hungary became a member of the Schengen zone, which means that border crossings became absolutely free, which may have boosted local cross-border tourism. Nevertheless, the data show just the opposite. Due to the even more open borders, the wealthy travelled even more to international destinations, whereas the poorer classes could afford less and less travelling even within the country, especially when the 2008 economic crisis hit Hungary. Our survey demonstrates that the wealthier western part of Hungary (the socalled Transdanubia) is only responsible for relatively few tourists to Aggtelek, and the area of attraction of Aggtelek is practically restricted to eastern Hungary, though the capital city, Budapest is still an important source of visitors travelling to Aggtelek (Fig. 7). Finally, the downward trend came to an end some years ago, and a slight increase was even observed in the number of tourists. At present, however, it is not possible to say whether this marks the start of a new uptrend or is just a temporary development.

\section{Lessons from the Tourist Questionnaires}

In this section, we analyse some characteristics of Aggtelek tourism including tourists' motivations and the role of geotourism. The tourist questionnaires were answered by 380 persons, of whom 44 people (11\%) completed the Slovakian or English language version. This corresponds to the national park's own measurements i.e. that about $10-15 \%$ of the tourists are foreign. Nonetheless, it should also
Fig. 6 Annual visitor numbers at Baradla Cave. NP: date of the foundation of Aggtelek National Park (1985), WH: date of the UNESCO World Heritage title (1995)

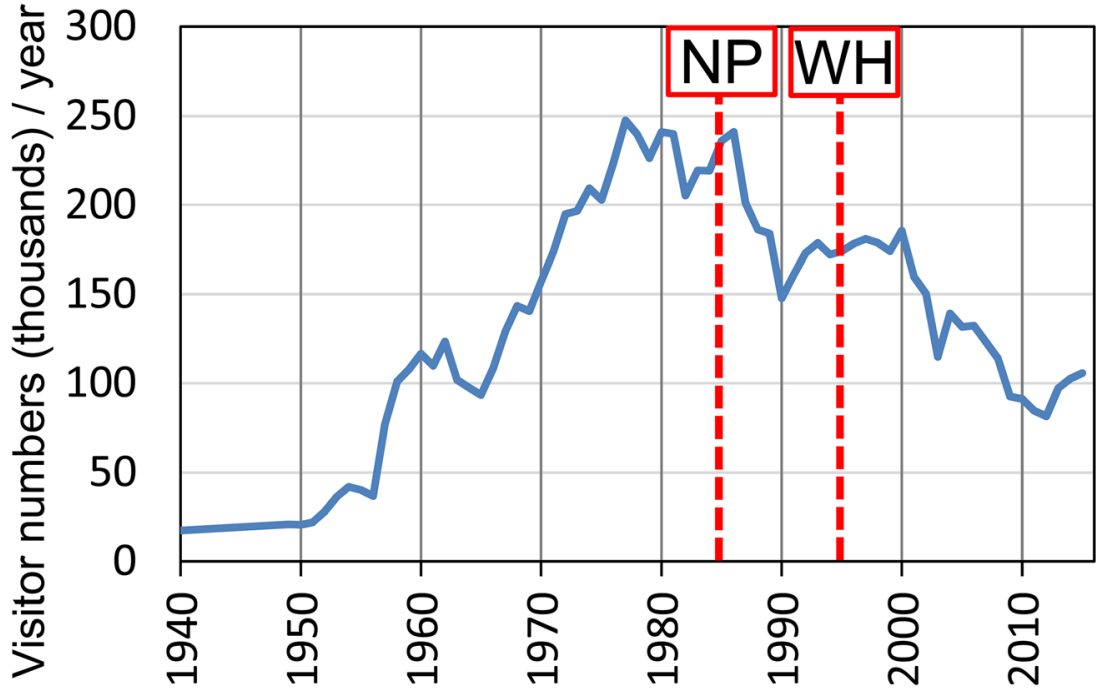




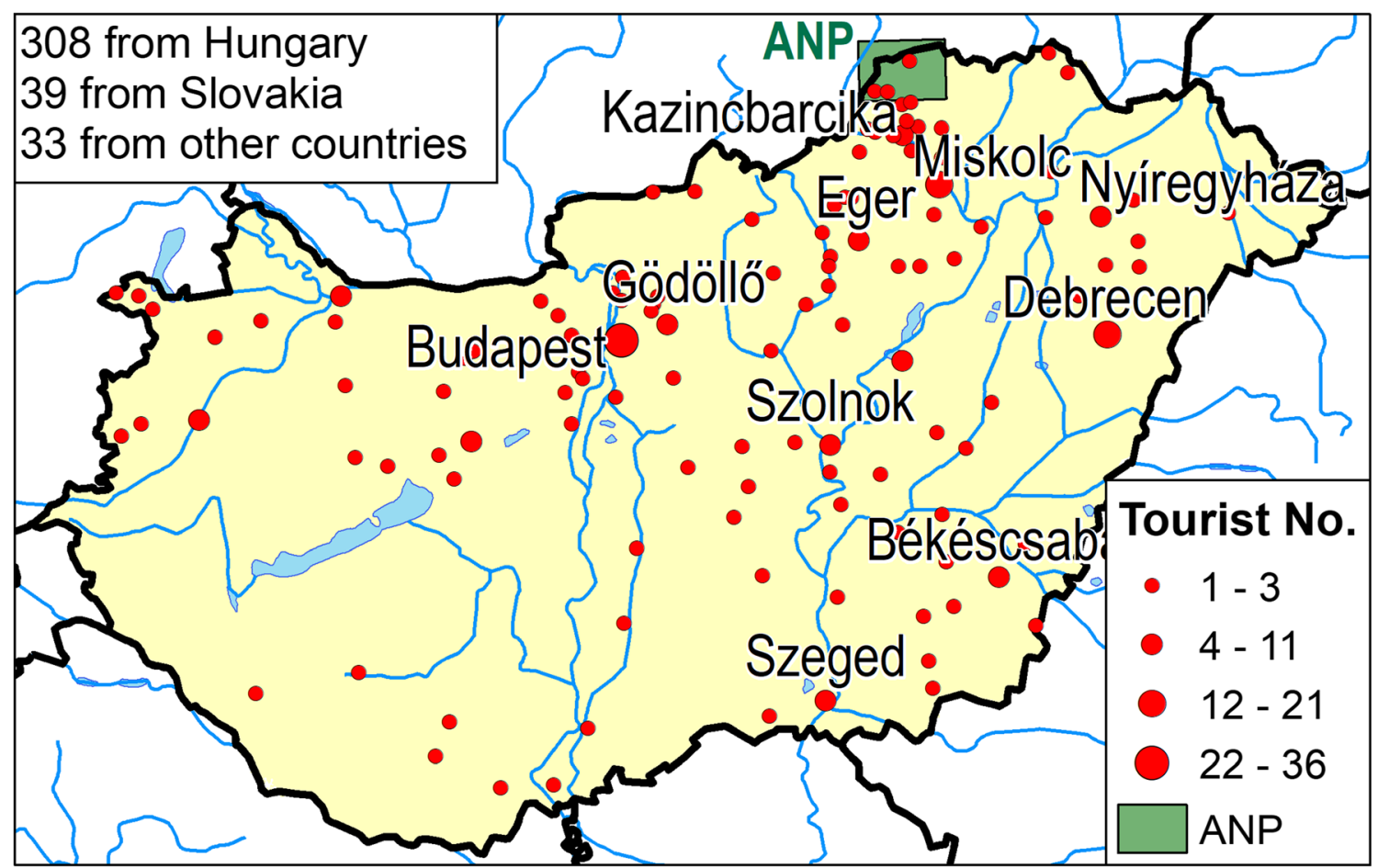

Fig. 7 Number of visitors, who completed the questionnaire, by residence

mentioned that ethnic Hungarians living in neighbouring or other countries also completed the Hungarian version, and so

Table 1 Some general data of our tourist survey

\begin{tabular}{lrr}
\hline & Number & $\%$ \\
\hline Questionnaire language & \\
Hungarian & 336 & 88 \\
English & 24 & 6 \\
Slovakian & 20 & 5 \\
Country of residence & & \\
Hungary & 308 & 86.8 \\
Slovakia & 39 & 11.0 \\
Other & 33 & 9.3 \\
Sex & & \\
Male & 168 & 44 \\
Female & 212 & 56 \\
Age & & \\
14-18 & 21 & 6 \\
18-30 & 73 & 19 \\
30-50 & 172 & 45 \\
50-65 & 83 & 22 \\
Over 65 & 31 & 8 \\
Education & & 79 \\
Primary school & 26 & 7 \\
Secondary school & 166 & 44 \\
University & 188 & 49 \\
Total & 380 & 100 \\
\hline
\end{tabular}

the number of people with residence in another country is 72 $(20 \%)$. General data about the respondents is presented in Table 1. Some general information on the tourists: as in the case of other nature-based tourist attractions, there is a high proportion of one-day tourists (59\%) and this raises certain problems. Moreover, there is a high seasonality in tourist numbers, which is also a disadvantage. On the other hand, $72 \%$ of tourists are recurrent tourists, which is a rather positive characteristic.

As the primary aim of tourists is to visit the Baradla Cave, we may call all visitors sensu lato "geotourists" (Dowling and Newsome 2006; Hose 2008), because they view a geologic value, and due to information boards and cave guides they are also "educated" in a certain sense. Using the questionnaire survey, we examined the awareness of geotourism, and also the geotourist identity. In response to the question "Have you ever heard the expression: 'geotourism'?", 62\% answered 'yes'. However, we believe that this proportion is too high, and it is the result of the fact that people generally do not admit their ignorance. As a kind of check, we put in a simple question "Do you know what is the meaning of the word 'KARST'?" to test the basic geologic knowledge of visitors. $50 \%$ said 'yes', and a significant proportion of them relatively correctly described the meaning of the word. Finally, the last question in this issue was "Are you to some extent a 'geotourist'?", to which $20 \%$ answered 'yes'. Thus, geotourism unambiguously exists at Aggtelek Karst region even sensu stricto. However, ANP managers do not consider geotourism an important issue, and although they are aware of 
this notion, they think it negligible for ANP, except of course the cave-related issues, which were considered as highly important by all interviewed managers. They also noted that there are no (human) resources in ANP to promote the issue of geotourism, and possibly to start a process aimed at creating a geopark. At this juncture, we would note that there are examples of this approach in Hungary, when a national park plays a significant role in the professional support of a geopark. This is true for the existing Bakony-Balaton UNESCO Global Geopark and for the Bükk Region Geopark (Baráz et al. 2018), which is presently in development.

The tourist motivations were examined using several questions. The Hungarian and foreign language questionnaires had some minor differences in the optional answers (there were some additional answer options in the Hungarian version). For the question "Why did you personally choose this site?" (Fig. 8), the most popular answer among Hungarians was: "I wanted to see the famous Aggtelek Dripstone Cave" (49\%), and $33 \%$ checked the answer "I'm generally interested in caves". The option "I wanted an adventurous tour" was only selected in $17 \%$ of the cases, which means that adventure is not so important, but is an existing viewpoint in the motivations of Baradla visitors. In the Hungarian version, there was a question about the values of the landscape (Fig. 9). Of the

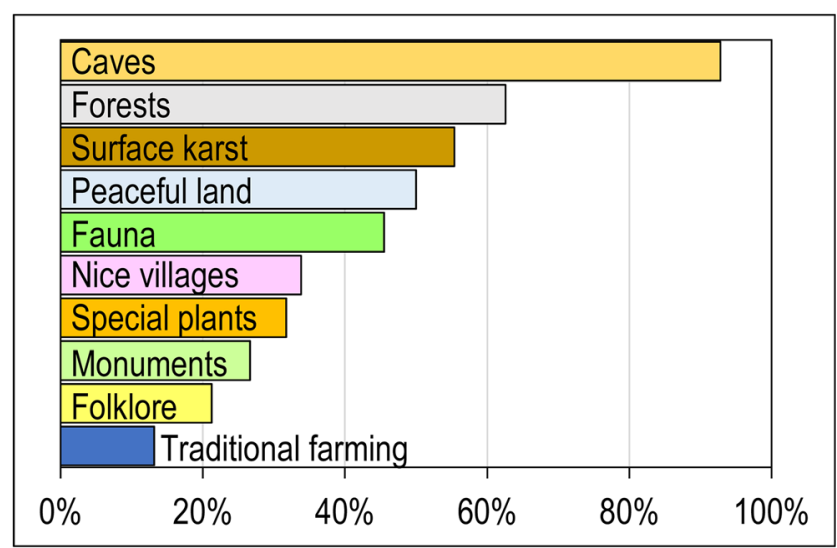

Fig. 9 Values of Aggtelek National Park as appreciated by tourists

answers given, "caves" was overwhelmingly the most frequent $(93 \%)$ before "forests" (63\%) and "surface karst" (55\%), underlining that tourists visit ANP because of its geological/geomorphological values. As for the foreign questionnaires, $68 \%$ of tourists checked the answer "I'm interested in caves", and $27 \%$ selected "I'm interested in karst terrains". The demand for surface hiking is clearly much lower, as only $29 \%$ of all respondents answered that they also plan a surface hike. By comparison, a surprisingly high $91 \%$ answered that they consider education trails slightly or very important.
Fig. 8 Personal motivations of tourists visiting Aggtelek National Park. a Hungarian tourists, $\mathbf{b}$ foreign tourists

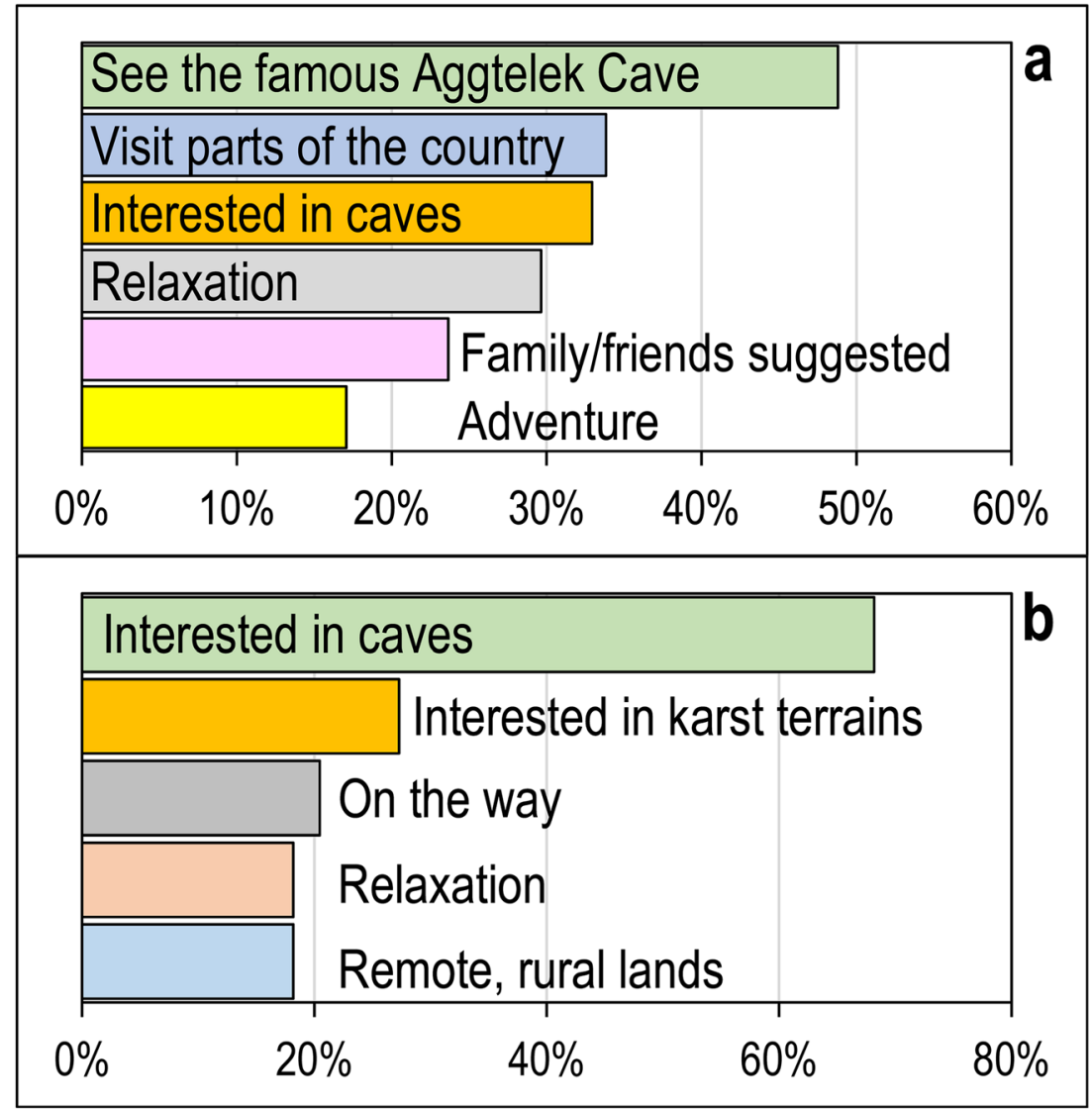


Internationally, research at several locations has shown how important it was for tourists if an area was declared a national park or a UNESCO World Heritage (Reinius and Fredman 2007). In our questionnaire, there were two questions about this ("Was it important for you that Aggtelek is a National Park?" and "Was it important for you that the Aggtelek caves are part of the World Heritage?") and three optional answers (not at all/slightly/very importantly) to each question (Fig. 10). For more than half of the Hungarian tourists $(52 \%)$ the "national park" title is "not at all" important, whereas this answer is much less frequent (16\%) in case of foreign tourists. The "World Heritage" title is more important for all groups, but foreign tourists selected the "very important" option much more frequently (42\%) than Hungarian visitors (only 25\%).

In addition to tourists' motivations, it is essential to know how tourists get information about ANP (Fig. 11). A remarkable result of our survey is that $49 \%$ of Hungarian tourists chose "school education" as an information source! (This option was only in the Hungarian questionnaire.) This means that public education still has a very significant role in (geo)tourism, and second, that it is a key question for Aggtelek to remain in the curriculum of elementary schools for the future as well. In this context, there is also a terminological question: the official/

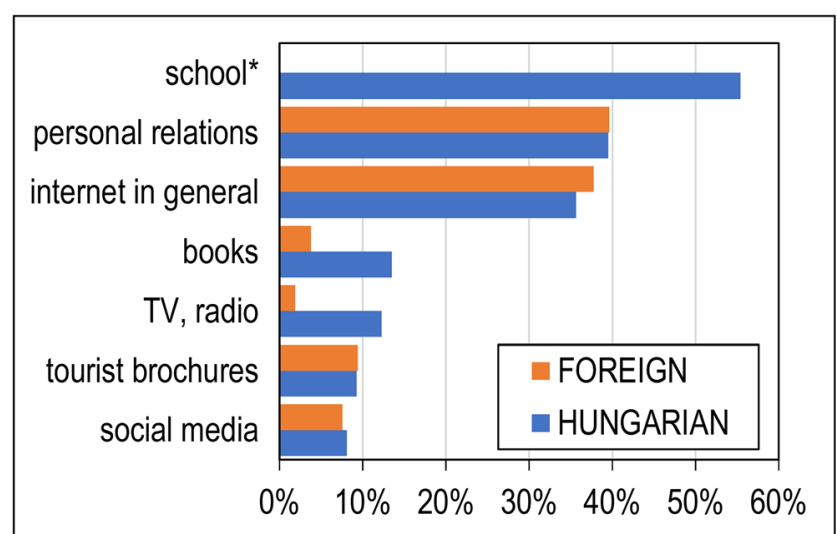

Fig. 11 Information source of tourists visiting Aggtelek National Park, a Hungarian tourists, $\mathbf{b}$ foreign tourists

speleological name of the cave is Baradla, but the public knows it — primarily from school — as the "Aggtelek Dripstone Cave". Our survey demonstrates that this popular name is of great significance, and besides the official name it should be used in the future as well, because people can link it to the settlement of Aggtelek, which helps the tourism of ANP. The second most important information source is "personal relations" (40\%), whereas "internet in general" option is only the third (37\%), though this latter answer was significantly more popular in the
Fig. 10 Importance of the "National Park" (a) and of the "World Heritage" (b) titles, according to the visitors

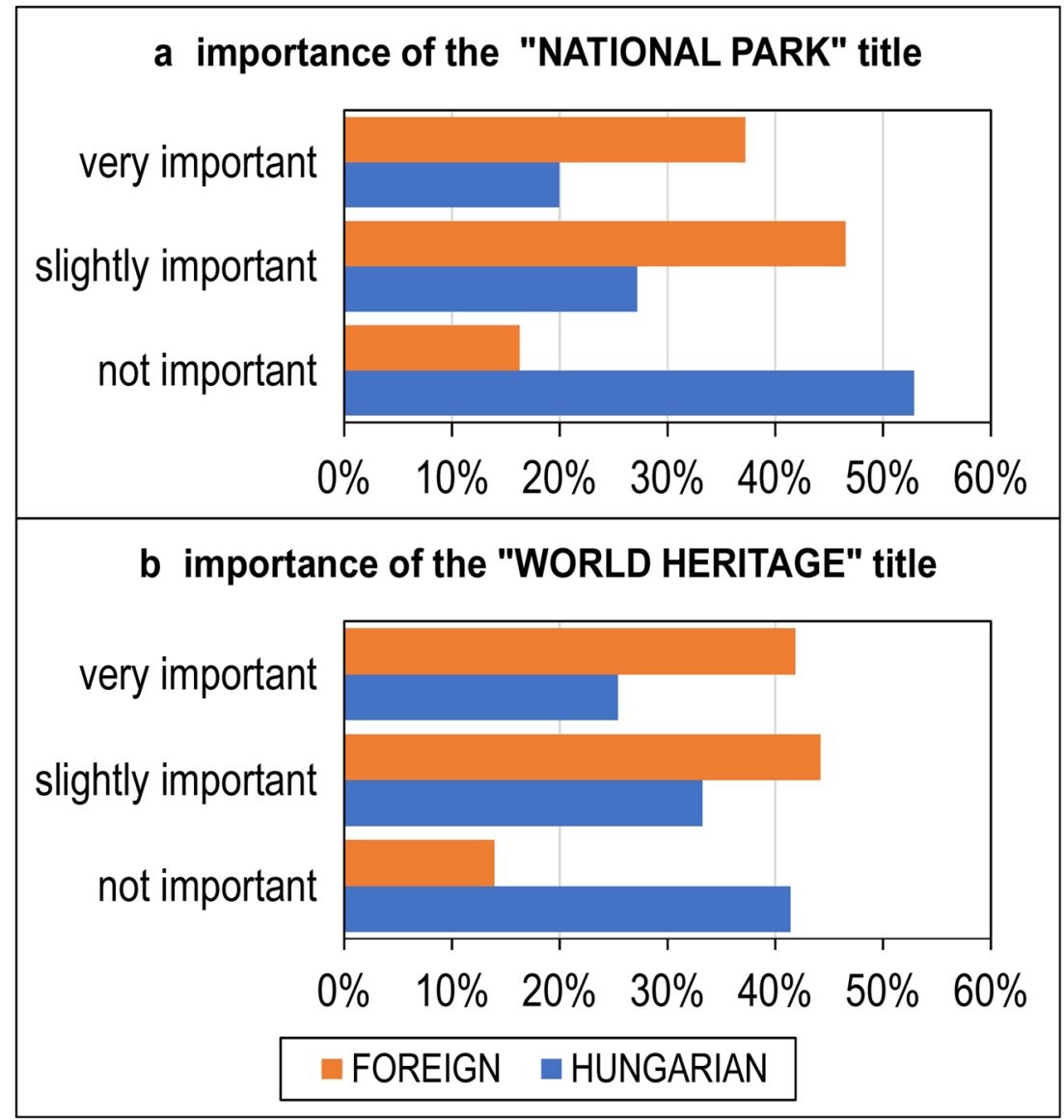


English version (63\%), but less frequent in the Slovak version $(25 \%)$. Quite surprisingly, "social media (e.g. Facebook)" was the least important information source $(8 \%)$ among the fixed answers.

\section{The Balance of Geo- versus Bioconservation}

As mentioned above, ANP was especially created for the protection and management of karst and caves. In the interviews with ANP managers, they clearly expressed that the national park's two most important aims, geoconservation and bioconservation, are of equal importance. The third in the order of aims is landscape protection (Fig. 12). In most Hungarian national parks, bioconservation is (much) more important than geoconservation, and thus we can say that in the special case of Aggtelek, the equality of the above aims is basically in agreement with the intention of the founders.

The interviews with ANP managers clarified that during everyday operations, biology related activities and land management receive a higher proportion of the budgetary and human resources. However, the importance of the caves is acknowledged by all of the managers. The budget of large projects funded by different organizations (EU or state) occasionally surpass the base budget of the national park and they may shift the balance either towards geoconservation or towards bioconservation (or land management). To see the proportion of geoconservation in terms of funding, we present some data from ANP. In the period 2007-2013, the ANP received EUR 10.6 million of funding from the EU, of which EUR 2 million was spent on abiotic goals. In the period 2014-2020, ANP received EUR 13.8 million, of which EUR 3.1 million was spent on abiotic goals, i.e. the proportion of geoconservation in these projects is around $20 \%$. Even if it is the smaller part, it is very significant, and while bioconservation needs a lot of everyday activities, in geoconservation the different measures may have longer-term results, and so this distribution of financing is in agreement with geoconservation and other goals according to ANP managers. Here we briefly mention some of

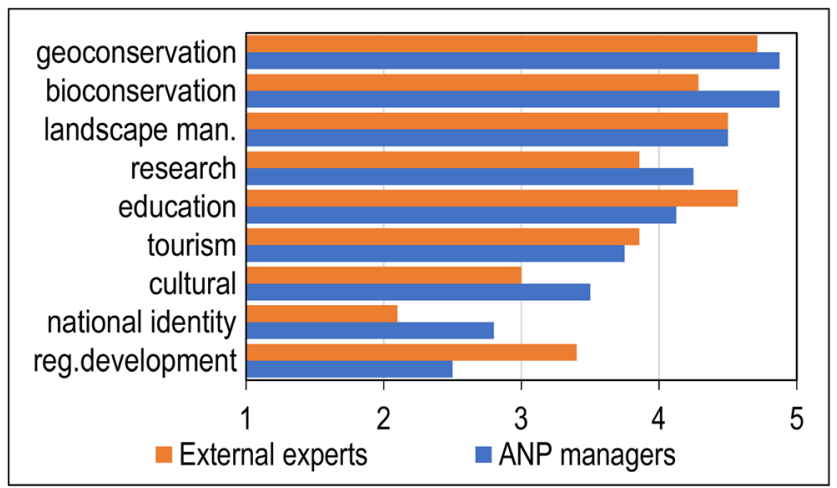

Fig. 12 Order of aims of Aggtelek National Park (ANP) according to external experts and ANP managers (1: not important, 5 : most important). man.: management, reg.: regional the geoconservation related tasks supported by these EU projects. For instance, parts of the former iron mine passages in Esztramos Hill were stabilized, which makes it possible to reach the spectacular caves found in this hill (e.g. Rákóczi Cave). When more passages become safe, Esztramos Hill will become suitable for the presentation of the mining history of this area in an adventurous and authentic way. Another project supported the reconstruction of lighting in several show caves using up-to-date LED technology. A third project made it possible to thoroughly measure the main branch of Baradla cave using 3D LiDAR technology. Béke Cave, a fascinating stream cave discovered in the 1950s, is available only for special groups. However, it had to be closed for several years due to high $\mathrm{CO}_{2}$ concentration. Ventilation was improved by cleaning and widening certain passages within the framework of a project, and thus the $\mathrm{CO}_{2}$ concentration was lowered to a safe level. Geological type sections throughout the karst area were also cleaned from overgrown vegetation. So, these projects have an impact on geotourism and also on local earth science research (such as water tracing, microclimate or speleobiology).

The interviews with external experts included mostly earth scientists or cavers, so it is less surprising that most of them expressed the opinion that geoconservation should have a slightly higher emphasis in ANP. Some of the interviewees even felt that bioconservation is a bit over-emphasized in ANP, and as a symbolic fact, they mentioned that in the logo of ANP there is a salamander instead of a cave or a more closely cave-related animal (Fig. 13). Nonetheless, most of them acknowledged that geoconservation and bioconservation are well-balanced in ANP, and deviations from equilibrium are only small.

In order to judge the scientific output of geologic/ geographic versus biologic research in ANP, we carried out a search in the largest Hungarian journal database (https://

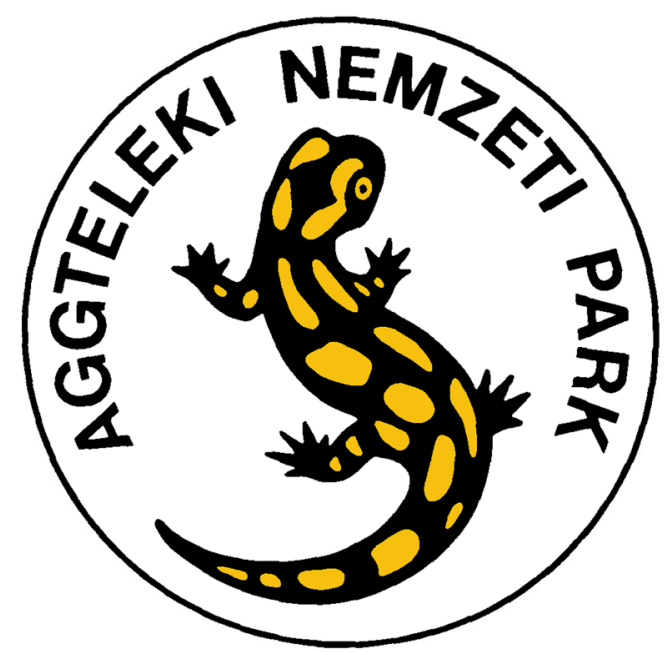

Fig. 13 Logo of Aggtelek National Park 
matarka.hu/) and found 422 publications related to the word "Aggtelek". Two hundred and thirty-five of them were published in scientific journals and 187 in popular magazines. After a thematic categorisation, we concluded that biology (48\%) and earth sciences (39\%) are dominant in the scientific issues, but popular articles are more diverse, including historical, touristic, archaeological, architectural, agrarian and folklore topics, in addition to $25 \%$ geology/geography and $19 \%$ biology related papers. The temporal changes presented in Fig. 14 are also interesting. Early on, there were only earth science papers, and biological articles appeared only in the second half of the twentieth century, but one can observe an abrupt increase in biological papers in the 1980s, surpassing even cumulatively the number of geo-publications. However, as for the international output, it is observed that according to Scopus database, geosciences are still dominant if Aggtelek is the topic, because $61 \%$ of Aggtelek-related publications come from earth sciences, in contrast to $31 \%$ from biological research.

\section{Regional Development and ANP}

In the official documents (founding document, rules of organization and operation) of ANP, regional development is not mentioned at all, since it is generally not among the official aims of nature protection organizations. According to this background, ANP managers put regional development in last place in the order of national park goals (Fig. 12). Nevertheless, during the interviews many of them expressed that ANP should and can do certain things in favour of local development. Especially in a microregion which faces several social problems (emigration, ageing, unemployment). In the following, we present how ANP impacts the socioeconomic situation of the surroundings.
First of all, this occurs in its role as an employer. In the microregion, the national park is the largest employer. At present, ANP officially has 130 permanent employees. About twothirds of their salaries are covered by the state budget, but the remaining one-third must be produced by the national park itself. The self-generated incomes of the national park mainly originate from cave tourism, area-based agricultural subsidies and various project funds. In addition to the permanent employees, another 110 people were employed by the national park in the so-called "Public Work Scheme". The public employment system is a special form in Hungary, its main task is to activate long-term unemployed people and to prevent permanent job seekers from exiting working life. It is mainly for people with low education and no professional skills, living in regions where market employment possibilities are limited. The Ministry of Interior offer temporary employment to these individuals by financing the direct expenses on their employment. National parks had the possibility to employ these people in the framework of this system. However, national parks were abruptly excluded from this system in July 2018, and thus public workers at ANP lost their employment, resulting in some tensions. Beyond permanent or fixed-term employment, ANP has contracts with local entrepreneurs, which means an additional 300 people who make money at least partly due to the presence of the national park. These numbers are remarkable in a microregion, where settlements of some 100 inhabitants are typical. The proportion of permanent employees within the population is high only in Aggtelek and Jósvafö settlements. Tourism is also an economic sector dependent on ANP, and it provides employment for another 150-200 people, who work in accommodation business or commerce. Therefore, a very high proportion of local people are directly or indirectly affected by the presence of ANP. In addition to the aforementioned positive effects, some local people mentioned certain negative effects, too, which are
Fig. 14 Cumulative number of journal articles mentioning the word "Aggtelek" in

MATARKA - a Hungarian bibliographic database

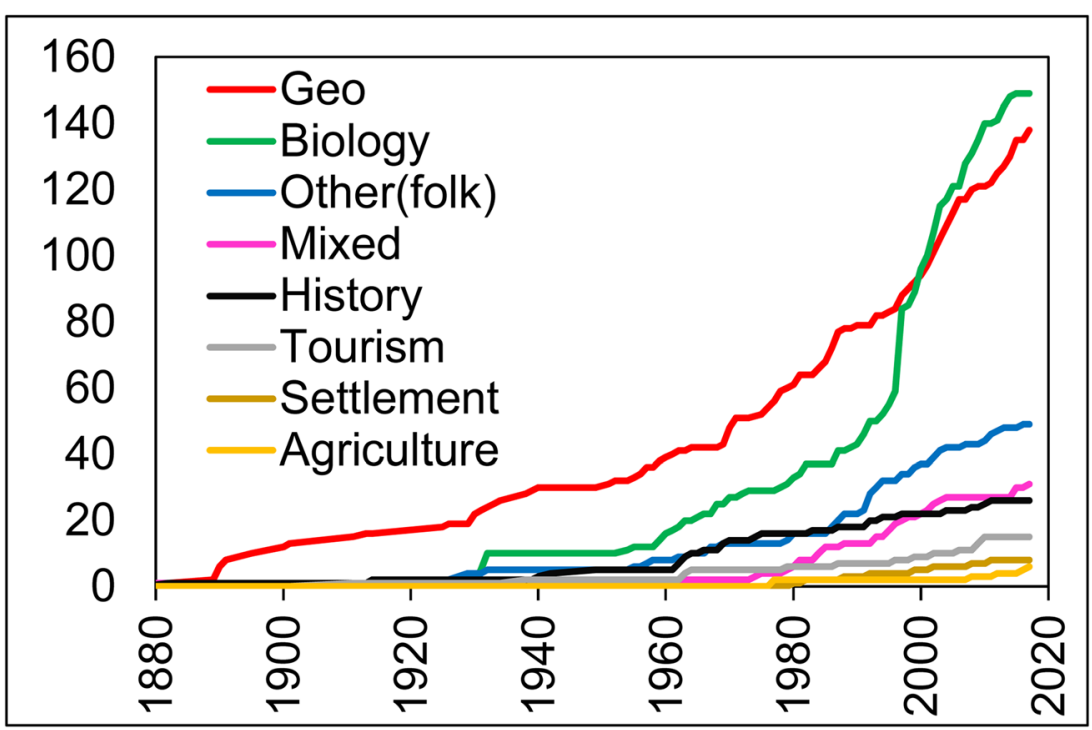


generally due to protection related limitations (e.g. prohibition of wood or other plant collection in the protected area; complicated authorization procedures for any investment).

Furthermore, there is a conflict with local people about the share of the profit from cave tourism. Some people from Aggtelek and Jósvafö emphasize that the cave was visited even before the national park was created, and that there were more visitors in those days than now. In addition, in those days, the settlement had a more significant share from the cave business. A further complicating factor is that both Aggtelek and Jósvafö would like to get a certain part of the profit, because the Baradla Cave has tourism access sites in both villages. However, the present situation is that the management of the cave and also the profit of cave tourism is under the authority of ANP. Nevertheless, the national park uses it for the benefit of local people as well, but some of the local people do not acknowledge this. Probably, the benefits for the settlements should be communicated more effectively. Furthermore, ANP is unquestionably a guarantee for the protection and professional management of the Baradla Cave.

Based on the interviews, it is perceivable that the philosophy of ANP is in a transitional phase now, due to both personal and deeper socio-economic reasons. Previously, the general principle was that ANP, as an organization with relatively significant human and financial resources (in a local context), should provide certain operation sectors within the microregion including accommodation and other tourist institutions as well. However, in the present situation when the state budget is decreased year by year, and thus human resources are also cut, ANP can undertake less, and tries to focus only on direct nature protection issues, while leaving the economic development (in tourism and other sectors) for local entrepreneurs. Nonetheless, local entrepreneurship is rather weak in the microregion for several reasons and entrepreneurs do not have enough capital.

\section{Discussion}

Based on the above aspects, we can compare the decreasing visitor numbers of ANP during the last three decades to the worldwide growing general tourist trend (UNWTO 2019; Kuenzi and McNeely 2008). First, we note that the general growing trend masks many individual cases. In fact, when either caves or karstic national parks are considered, there are examples for quickly growing visitor numbers as well as for stagnating or declining trends (Spate and Spate 2013). Some examples for quickly growing cave visitor numbers are Postojna Cave in Slovenia (Šebela et al. 2015) or Mogao Grottoes in China (Jinshi 2014). The preliminary data of Spate and Spate (2013) show that in Western Europe or in Slovakia, the visitor numbers tended to stagnate or fall in the twenty-first century. Gessert et al. (2018) published an analysis of show cave visitor numbers in Slovakia. Their dataset clearly indicates that there was a decline in cave tourism after 2008, that is due to the financial crisis and the change of Slovakia's currency to the euro. Furthermore, they found that the proximity of other cultural and natural facilities, the quality and amount of services, and the overall economic situation also affect cave visitor numbers. The situation in Hungary is similarly complex. Using official visitor numbers data received from the State Secretariat for Environmental Affairs (Ministry of Agriculture), it is observed that most caves had more visitations in the 1970s and 1980s than now. In the twenty-first century, the only cave with a significant increase in visitor numbers is the Tapolca Lake Cave, which at present attracts more tourists than the Baradla Cave despite the fact that the Baradla Cave is much larger and richer in speleothems. Tapolca Lake Cave is found in the Balaton-felvidék National Park and in the Bakony-Balaton UNESCO Geopark. Besides the good management and the possibility of a short underground boat trip, the popularity of this cave is definitely due to the fact that it is close to the western Hungarian Balaton Lake, which is a very popular tourist resort. Similar results were mentioned by Bao and Zhang (2006), who found that cave visitor numbers are dependent on nearby tourist attractions. Spate and Spate (2013) enumerate several potential factors which can affect the number of cave visitors. They categorize the factors as international (e.g. oil prices, disease outbreaks), national (e.g. Gentle Revolution in Slovakia) or local (e.g. weather events, roadworks).

As for karstic national parks visitations, the increase of tourism can be observed in certain cases (Mari and Telbisz 2018), for instance in the Croatian national parks (Petrić and Mandić 2014). In some cases, the rise in visitor numbers is even too fast, putting an extra burden on nature, such as in Krka National Park (NPKRKA 2018) or in Plitvice Lakes National Park (UNESCO World Heritage Committee 2017). By contrast, there are national parks at "remote" locations, where karst features and show caves are not enough to attract people to the area. The neighbouring Slovak Karst National Park can be mentioned as an example (Clarke et al. 2001; Nolte 2004). In Hungary, the situation is varied (Pádárné Török 2018): Bükk National Park, which has significant karst areas, has been able to increase its visitor numbers since 2005 . The partly karstic Balaton-felvidék National Park and DunaIpoly National Park, which are near tourist hotspots (Balaton Lake and Budapest, respectively) have also seen significant growth in visitor numbers. By contrast, Duna-Dráva National Park, which also includes a karstic area, can be characterized by stagnating visitor numbers since 2005 . This latter national park lies in the southern part of Hungary, in a region, where socio-economic conditions are generally weaker. So, considering the above examples, we believe that in the case of ANP, visitor numbers are admittedly affected by the fact that Aggtelek is far from the populatar tourist destinations. 
However, it is possible that well-designed marketing incorporating geotourism elements could partially improve the situation. More generally speaking, it is concluded that visitor numbers are significantly influenced by broader socioeconomic factors, and the scientific value of a cave or the efforts of the local stakeholders may be occasionally less effective.

The "feeling of remoteness" at Aggtelek mentioned by many interviewees is certainly an interesting fact. The possible reasons are the following: transport inconveniences (bad road conditions at some places, infrequent public transport), the rural and traditional character of the area, the hilly and forested landscape, the weak socio-economic development in general, and the lack of services (e.g., specialized shops). In general, managers and mayors consider this "feeling of remoteness" as a disadvantage, because it results less tourists and makes socio-economic development more difficult. However, the "feeling of remoteness" can be considered also as a value - as expressed by some tourists and even by some local people, who believe that the "quiet, rural landscape" is a positive characteristic.

As for the depopulation of the study area, we can compare it to European and Hungarian trends. In general, rural depopulation is a widespread and thoroughly studied phenomenon in Europe and in other continents alike. On a European scale, most rural settlements have decreasing populations, but the exact proportions vary. In Hungary, the proportion of shrinking settlements $(81 \%$ ) was among the highest in the EU in the period 2001-2011, while in Slovakia, this figure was much lower (42\%; ESPON 2017). In Hungary, $31 \%$ of settlements are classified as rural settlements (based on Hungarian Central Statistical Office data). The mean annual population change in this category was $-0.8 \%$ for the period $1970-1990$, and $0.06 \%$ for the period 1990-2011. For the studied settlements of the Aggtelek Karst, these values were $-1.4 \%$ and $-0.6 \%$ respectively, which means that this microregion is more seriously impacted by depopulation than other rural areas in Hungary. Furthermore, several settlements experienced a mean annual decrease of $-3 \%$ to $-5 \%$ during these periods, underlining their critical demographic situation.

The composition of Aggtelek tourists is somewhat different from the typical composition usually observed in geotouristic or ecotouristic sites. As Allan (2011), Zgłobicki and BaranZgłobicka (2013), Štrba (2019) demonstrated "geotourists are predominantly young to middle-aged, well-educated, and preferring internet as their primary source of information" Allan (2011) used onsite questionnaires in Australia and Jordan, whereas Zgłobicki and Baran-Zgłobicka (2013) and Štrba (2019) conducted online surveys focusing on SE Poland and Slovakia, respectively. In our ANP survey, middle-aged people are the most frequent. People with a university degree are the majority, but their proportion is not as high as in the samples of Zgłobicki and Baran-Zgłobicka (2013) or Štrba
(2019). One reason for this is that many people come to Aggtelek for recreation with family from nearby areas, where the proportion of highly educated people is lower. Another difference is that the main information source is not the internet, but school education and personal relations. It can be explained by the same factors. Since the proportion of recurrent tourists is high, we can agree the opinion of Allan et al. (2015), who wrote that "retaining the first time tourists or geotourists, is more effective than promoting the geosites to new tourists".

One view often articulated in the literature is that cooperation with local people is indispensable for the effective operation of a national park (Butler and Boyd 2000; Papageorgiou and Kassioumis 2005; Frost and Hall 2009; PietrzykKaszyńska et al. 2012). In the ANP interviews, both sides (ANP managers and mayors) clearly expressed the need for cooperation. However, a systematic consultation or forum does not exist, which could serve as a basis for such cooperation. Therefore, coordination between ANP managers and local leaders is rather informal and ad-hoc.

\section{Conclusions}

The geoheritage of Aggtelek Karst is highly diverse due to the exokarst and especially the endokarst features. These natural values are complemented by anthropogenic factors, such as the remains of mining history. Geotourism in the broader sense is of primary importance in ANP due to the Baradla Cave. However, it is present rather in an "anonymous" form, and geotourism is not part of the strategic thinking of the national park. The demand for geotourism in the strict sense is less significant, but does exist. The more explicit expression of geotourism would be important, in order to build further tourism links. Moreover, it is also recommended that ANP should be viewed itself as part of a larger touristic destination, which includes a larger region in NE-Hungary and incorporates also the areas on the other side of the state border. The relationship between ANP and Slovak Karst National Park is good, but the linguistic and cultural opportunities due to Hungarian people living in Slovakia could be more effectively utilized in tourism development. A coordinated (geo)touristic management would be preferable for both countries, but it is still to be developed. In ANP, everybody (managers, mayors, local people, external experts) agree that tourism should be developed to higher levels, and that the harmful effects of tourism are negligible at present. The ANP managers hope that incomes from tourism can replace to some extent the decreasing state revenues, whereas local people expect more employment from tourism.

It seems that in the values and operation of ANP, the geoand bioconservation is balanced by consensus, that should be preserved by all means. As one of the experts said, 
geoconservation cannot be realized without bioconservation and vice versa. This principle should be recommended to other karstic national parks as well.

Finally, it is concluded that the existence of ANP is of particular importance for local people. In spite of all difficulties, the look of the villages, the employment possibilities, and the general socio-economic situation is relatively better in ANP, than in the neighbouring hilly areas, which are similar in relief and in "remoteness", but are not built up of karstifiable rocks, and therefore have no special geosites in their areas and consequently they are not protected by a national park. Thus, we conclude that the (geo)conservation in the case of ANP has a positive impact on local development, but it is not enough to solve deeply rooted social problems. However, for geotourists, Aggtelek National Park is a perfect destination with its varied landforms and caves.

Acknowledgements The authors are grateful to two anonymous reviewers for their helpful comments and to Kimo Logan for his stylistic and grammatical corrections.

Funding Information Open access funding provided by Eötvös Loránd University (ELTE). This research was supported by the National Research, Development and Innovation Office Hungary (NKFIH) K124497 project.

Open Access This article is licensed under a Creative Commons Attribution 4.0 International License, which permits use, sharing, adaptation, distribution and reproduction in any medium or format, as long as you give appropriate credit to the original author(s) and the source, provide a link to the Creative Commons licence, and indicate if changes were made. The images or other third party material in this article are included in the article's Creative Commons licence, unless indicated otherwise in a credit line to the material. If material is not included in the article's Creative Commons licence and your intended use is not permitted by statutory regulation or exceeds the permitted use, you will need to obtain permission directly from the copyright holder. To view a copy of this licence, visit http://creativecommons.org/licenses/by/4.0/.

\section{References}

Allan M (2011) Toward a better understanding of motivations for a geotourism experience: A self-determination theory perspective. $\mathrm{PhD}$ Dissertation, Edith Cowan University, Western Australia

Allan M, Dowling RK, Sanders D (2015) The motivations for visiting geosites: the case of Crystal Cave, Western Australia. GeoJournal of Tourism and Geosites 16:141-152

Ateș HÇ, Ateș Y (2019) Geotourism and rural tourism synergy for sustainable development - Marçik Valley case - Tunceli, Turkey. Geoheritage 11:207-2015. https://doi.org/10.1007/s12371-0180312-1

Balmford A, Beresford J, Green J, Naidoo R, Walpole M, Manica A (2009) A global perspective on trends in nature-based tourism. PLoS Biol 7(6):e1000144. https://doi.org/10.1371/journal.pbio. 1000144

Bao J, Zhang C (2006) The TALC in China's tourism planning: case study of Danxia Mountain, Guangdong Province, PRC. In: Butler
RW (ed) The tourism area life cycle. Channel View Publications, Clevedon, pp 107-115

Baráz C, Holló S, Telbisz T (2018) Creation of a new geopark in the Bükk Region (Hungary) - a bottom-up initiative. In: Głowniak E, Wasiłowska A, Leonowicz P (eds) Geoheritage and conservation: modern approaches and applications towards the 2030 Agenda. 9th ProGEO Symposium, Chęciny, Poland, 25-28th June, 2018, Programme and abstract book. Faculty of Geology. University of Warsaw, pp 67-68

Bella P, Veselskỳ M, Gaál U, Minár J (2016) Jósvafo paleo-Polje: morphology and relation to the landform evolution of Aggtelek karst and Jósva River valley, Hungary. Z Geomorphol 60:219-235. https://doi.org/10.1127/zfg/2016/0212

Bella P, Bosák P, Braucher R, Pruner P, Hercman H, Minár J, Veselský M, Holec J, Léanni L (2019) Multi-level Domica-Baradla cave system (Slovakia, Hungary): middle Pliocene-Pleistocene evolution and implications for the denudation chronology of the Western Carpathians. Geomorphology 327:62-79. https://doi.org/10.1016/j. geomorph.2018.10.002

Borbás E, Kovács J, Fehér K, Vid G, Hatvani IG (2011) Water chemistry analysis in the sediment of Baradla Cave, Hungary. Central Eur Geol 54:367-380. https://doi.org/10.1556/CEuGeol.54.2011.4.5

Bosák P, Hercman H, Kadlec J, Móga J, Pruner P (2004) Palaeomagnetic and U-series dating of cave sediments in Baradla Cave, Hungary. Acta Carsologica 33:219-238

Božić S, Tomić N (2015) Canyons and gorges as potential geotourism destinations in Serbia: comparative analysis from two perspectivesgeneral geotourists' and pure geotourists'. Open Geosci 7:531-546. https://doi.org/10.1515/geo-2015-0040

Brilha J (2002) Geoconservation and protected areas. Environ Conserv 29:273-276

Butler RW, Boyd SW (eds) (2000) Tourism and national parks: issues and implications. Wiley, Chichester

Cigna AA, Forti P (2013) Caves: the most important geotouristic feature in the world. Tourism and Karst Areas 6:9-26

Clarke J, Denman R, Hickman G, Slovak J (2001) Rural tourism in Roznava Okres: a Slovak case study. Tour Manag 22:193-202. https://doi.org/10.1016/S0261-5177(00)00038-8

Crofts R (2018) Putting geoheritage conservation on all agendas. Geoheritage 10:231-238. https://doi.org/10.1007/s12371-0170239-y

Czuppon G, Demény A, Leél-Őssy S, Óvari M, Molnár M, Stieber J, Kiss K, Kármán K, Surányi G, Haszpra L (2018) Cave monitoring in the Béke and Baradla caves (Northeastern Hungary): implications for the conditions for the formation cave carbonates. Int J Speleol 47: 13-28. https://doi.org/10.5038/1827-806X.47.1.2110

Demény A, Németh A, Kern Z, Czuppon G, Molnár M, Sz L-Ö, Óvári M, Stieber J (2017) Recently forming stalagmites from the Baradla Cave and their suitability assessment for climate - proxy relationships. Central Eur Geol 60:1-34. https://doi.org/10.1556/24.60. 2017.001

Dowling RK (2011) Geotourism's global growth. Geoheritage 3:1-13. https://doi.org/10.1007/s12371-010-0024-7

Dowling RK, Newsome D eds (2006) Geotourism. 1st ed (e-book). Routledge

ESPON (2017) Shrinking rural regions in Europe. https://www.espon.eu/ sites/default/files/attachments/ESPON\%20Policy\%20Brief\% 20 on $\% 20$ Shrinking\%20Rural\%20Regions.pdf. Accessed 30 Sept 2019

Evans BG (2005) Geoparks, coalfields and South Wales - a sustainable combination? Z Dtsch Ges Geowiss 156:373-380. https://doi.org/ $10.1127 / 1860-1804 / 2005 / 0156-0373$

Farsani NT, Coelho C, Costa C (2011) Geotourism and geoparks as novel strategies for socio-economic development in rural areas. Int $\mathrm{J}$ Tour Res 13:68-81. https://doi.org/10.1002/jtr.800 
Ford DC, Williams PW (1989) Karst geomorphology and Hidrology. Unwin Hyman, London

Frost W, Hall CM (eds) (2009) Tourism and national parks: international perspectives on development, histories and change. Routledge, London

Gaál L, Bella P (2005) Vplyv tektonických pohybov na geomorfologický vývoj západnej časti Slovenského Krasu. Slovenský Kras, Acta Carsologica Slovaca 43:17-36 (in Slovakian)

Galbács G, Kevei-Bárány I, Szőke E, Jedlinszki N, Gornushkin IB, Galbács MZ (2011) A study of stalagmite samples from Baradla Cave (Hungary) by laser induced plasma spectrometry with automatic signal correction. Microchem J 99:406-414. https://doi.org/ 10.1016/j.microc.2011.06.014

Gessert A, Nestorová-Dická J, Sninčák I (2018) The dynamics of tourist excursion ratios in Slovakia show caves from 2000 to 2014. Geografisk Tidsskrift-Danish Journal of Geography 118:173-183. https://doi.org/10.1080/00167223.2018.1503552

Gordon JE, Crofts R, Díaz-Martínez E, Woo KS (2018) Enhancing the role of geoconservation in protected area management and nature conservation. Geoheritage 10:191-203. https://doi.org/10.1007/ s12371-017-0240-5

Gradziński M, Hercman H, Nowak M, Bella P (2007) Age of black coloured laminae within speleothems from Domica Cave and its significance for dating of prehistoric human settlement. Geochronometria 28:39-45. https://doi.org/10.2478/v10003-0070029-7

Gruber P, Gaál L (2014) A Baradla-Domica-barlangrendszer: a barlang, amely összeköt. Aggteleki Nemzeti Park Igazgatóság, Jósvafö

Gruber P, Kereskényi E, Koltai G, Bárány-Kevei I (2012) Data on the hydrogeographical conditions of Baradla cave: seepage and drip waters. Acta climatologica et chorologica Universitatis Szegediensis 46:125-134

Gyuricza G, Sásdi L (2009) A Baradla-barlangrendszer kialakulásának kérdései a tágabb környezet földtani fejlõdésének tükrében. Földtani Közlöny 139:83-92

Han J, Wu F, Tian M, Li W (2018) From geopark to sustainable development: Heritage conservation and geotourism promotion in the Huangshan UNESCO Global Geopark (China). Geoheritage 10: 79-91. https://doi.org/10.1007/s12371-017-0227-2

Holl B (2007) A Baradla-barlang régészeti kutatása. Archaeologiai Értesítő 132:267-288

Hose TA (2008) Towards a history of geotourism: definitions, antecedents and the future. In: Burek CV, Prosser CD (eds): the history of geoconservation. Geol Soc Lond, Spec Publ 300:37-60. https://doi. org/10.1144/SP300.5

Jinshi F (2014) Tourism to the Mogao grottoes: overview of conservation challenges and countermeasures. In: Agnew N, Demas M (eds) Extended abstracts of the international colloquium. Visitor Management and Carrying Capacity at World Heritage Sites in China. Getty Conservation Institute, Los Angeles, pp 12-19

Kim SS, Kim M, Park J, Guo Y (2008) Cave tourism: tourists' characteristics, motivations to visit, and the segmentation of their behavior. Asia Pacific Journal of Tourism Research 13:299-318. https://doi. org/10.1080/10941660802280448

Kövér S, Fodor L, Judik K, Németh T, Balogh K, Kovács S (2009) Deformation history and nappe stacking in Rudabánya Hills (inner Western Carpathians) unravelled by structural geological, metamorphic petrological and geochronological studies of Jurassic sediments. Geodin Acta 22:3-29. https://doi.org/10.3166/ga.22.3-29

Kuenzi C, McNeely J (2008) Nature-based tourism. In: Renn O, Walker $\mathrm{KD}$ (eds) Global risk governance: concept and practice using the IRGC framework. Springer, Dordrecht, Netherlands, pp 155-178

Lazzari M, Aloia A (2014) Geoparks, geoheritage and geotourism: opportunities and tools in sustainable development of the territory. Geojournal of Tourism and Geosites 13:8-9
Less G (2000) Polyphase evolution of the structure of the AggtelekRudabánya Mountains (NE Hungary), the southernmost element of the inner Western Carpathians-a review. Slovak Geological Magazine 6(2-3):260-268

Liu W, Vogt CA, Lupi F, He G, Ouyang Z, Liu J (2016) Evolution of tourism in a flagship protected area of China. J Sustain Tour 24:203226. https://doi.org/10.1080/09669582.2015.1071380

Mari L, Telbisz T (2018) European National Parks with karst landscapes. In: Głowniak E, Wasiłowska A, Leonowicz P (eds) Geoheritage and conservation: modern approaches and applications towards the 2030 agenda. 9th ProGEO Symposium, Chęciny, Poland, 25-28th June, 2018, Programme and abstract book. Faculty of Geology, University of Warsaw, pp 94-95

McKeever PJ, Zouros N (2005) Geoparks: celebrating earth heritage, sustaining local communities. Episodes 28:274-278

Móga J (1999) Reconstruction of the development history of karstic water networks on the southern part of the Gömör-Torna karst on the bases of ruined caves and landforms. Acta Carsologica 28(2):159-174

Mose I (ed) (2007) Protected areas and regional development in Europe: towards a new model for the 21 st century. Ashgate Publishing, Aldershot, UK

Nolte B (2004) Sustainable tourism in biosphere reserves of east central European countries - case studies from Slovakia, Hungary and the Czech Republic. Policies, Methods and Tools for Visitor Management 2005:349-356

NPKRKA (2018) New sustainable management measures at Skradinski Buk. http://www.npkrka.hr/clanci/New-sustainable-measuresSkradinski-buk/405/en.html. Accessed 05 Oct 2019

NPS (2019) Visitation numbers. https://www.nps.gov/aboutus/visitationnumbers.htm. Accessed 4 Oct 2019

Pádárné Török É (2018) Ökoturizmus helye és szerepe a nemzeti park igazgatóságok feladatkörében. http://www.termeszetvedelem.hu/ user/browser/File/Okoturizmus/MNPH 2018/AM.pdf. Accessed 4 Oct 2019

Palmer AN (1991) Origin and morphology of limestone caves. Geol Soc Am Bull 103(1):1-21

Papageorgiou K, Kassioumis K (2005) The national park policy context in Greece: park users' perspectives of issues in park administration. J Nat Conserv 13:231-246. https://doi.org/10.1016/j.jnc.2004.11.001

Petrić L, Mandić A (2014) Visitor management tools for protected areas focused on sustainable tourism development: the Croatian experience. Environ Eng Manag J 13:1483-1495

Pietrzyk-Kaszyńska A, Cent J, Grodzińska-Jurczak M, Szymańska M (2012) Factors influencing perception of protected areas - the case of Natura 2000 in polish Carpathian communities. J Nat Conserv 20: 284-292. https://doi.org/10.1016/j.jnc.2012.05.005

Reinius SW, Fredman P (2007) Protected areas as attractions. Ann Tour Res 34:839-854. https://doi.org/10.1016/j.annals.2007.03.011

Schmid SM, Bernoulli D, Fügenschuh B, Matenco L, Schefer S, Schuster R, Tischler M, Ustaszewski K (2008) The Alpine-CarpathianDinaridic orogenic system: correlation and evolution of tectonic units. Swiss J Geosci 101:139-183. https://doi.org/10.1007/ s00015-008-1247-3

Šebela S, Turk J, Pipan T (2015) Cave micro-climate and tourism: towards 200 years (1819-2015) at Postojnska jama (Slovenia). Cave and Karst Science 42:78-85

Spate A, Spate J (2013) World-wide show cave visitor numbers over the recent past. ACKMA Cave and Karst Management in Australasia 2014 1:57-69

Stemberk J, Dolejs J, Maresova P, Kuca K (2018) Factors affecting the number of visitors in National Parks in the Czech Republic, Germany and Austria. ISPRS Int J Geo Inf 7:124-133. https://doi. org/10.3390/ijgi7030124

Stepišnik U, Trenchovska A (2018) A new quantitative model for comprehensive geodiversity evaluation: the Škocjan Caves Regional 
Park, Slovenia. Geoheritage 10:39-48. https://doi.org/10.1007/ s12371-017-0216-5

Stevens TH, More TA, Markowski-Lindsay M (2014) Declining National Park visitation: an economic analysis. J Leis Res 46:153-164. https://doi.org/10.1080/00222216.2014.11950317

Štrba L (2019) Analysis of criteria affecting geosite visits by general public: a case of Slovak (geo)tourists. Geoheritage 11:291-300. https://doi.org/10.1007/s12371-018-0283-2

Székely K (1998) A Baradla hazánk természeti csodája. In: Baross G (ed) Az Aggteleki Nemzeti Park. Mezőgazda Kiadó, Budapest, pp 201222

Szvoboda L (1998) A természetvédelem múltja, az Aggteleki Nemzeti Park jelene és jövője. In: Baross G (ed) Az Aggteleki Nemzeti Park. Mezőgazda Kiadó, Budapest, pp 12-17

Takácsné Bolner K (1998) Kristálybarlangok az Esztramos gyomrában. In: Baross G (ed) Az Aggteleki Nemzeti Park. Mezőgazda Kiadó, Budapest, pp 194-200

Telbisz T (2001) Új megközelítések a töbör-morfológiában az Aggtelekikarszt példáján. Földrajzi közlemények 125:95-108

Telbisz T (2011) Large-scale relief of the Slovak karst and Aggtelek karst (Gömör-Torna/Gemer-Turňa karst) - a DEM-based study. Hungarian Geographical Bulletin 60(4):379-396

Telbisz T, Bottlik Z, Mari L, Köszegi M (2014) The impact of topography on social factors, a case study of Montenegro. J Mt Sci 11:131-141. https://doi.org/10.1007/s11629-012-2623-Z

Telbisz T, Bottlik Z, Mari L, Petrvalská A (2015) Exploring relationships between karst terrains and social features by the example of GömörTorna karst (Hungary-Slovakia). Acta Carsologica 44:121-137. https://doi.org/10.3986/ac.v44i1.1739

Telbisz T, Imecs Z, Mari L, Bottlik Z (2016a) Changing humanenvironment interactions in medium mountains: the Apuseni Mts (Romania) as a case study. J Mt Sci 13:1675-1687. https://doi.org/ 10.1007/S11629-015-3653-0

Telbisz T, Látos T, Deák M, Székely B, Zs K, Standovár T (2016b) The advantage of LIDAR digital terrain models in doline morphometry compared to topographic map based datasets - Aggtelek karst (Hungary) as an example. Acta Carsologica 45(1):5-18. https:// doi.org/10.3986/ac.v45i1.4138

Telbisz T, Stergiou CL, Mindszenty A, Chatzipetros A (2019) Karst features and related social processes in the region of the Vikos Gorge and Tymphi Mountain (Northern Pindos National Park, Greece). Acta Carsologica 48:29-42. https://doi.org/10.3986/ac.v48i1.6806

Tózsa I (1996) Touristic potential of the Aggtelek karst region. Foldrajzi Ertesito 45:299-314

Trakolis D (2001) Perceptions, preferences, and reactions of local inhabitants in Vikos-Aoos National Park, Greece. Environ Manag 28: 665-676. https://doi.org/10.1007/s002670010251

UNESCO World Heritage Committee (2017) Report on the mission to Plitvice Lakes National Park, Croatia from 17 to 19 January 2017. https://whc.unesco.org/document/157749. Accessed 05 Oct 2019

UNWTO (2019) International tourism highlights, 2019 edition. World tourism organization. https://www.e-unwto.org/doi/pdf/10.18111/ 9789284421152 accessed 27 Sept 2019

Veress M, Unger Z (2015) Baradla-Domica: large cave system on the Hungarian-Slovak border. In: Lóczy D (ed) Landscapes and landforms of Hungary. World Geomorphological Landscapes. Springer International Publishing, Cham, pp 167-175. https://doi.org/10. 1007/978-3-319-08997-3 20

Zámbó L (1998) Felszínalaktani jellemzés. In: Baross G (ed) Az Aggteleki Nemzeti Park. Mezőgazda Kiadó, Budapest, pp 70-96

Zámbó L, Ford D, Telbisz T (2002) Baradla-barlangi cseppkőkoradatok a késő-negyedidőszaki klímaingadozások tükrében. Földtani Közlöny 132:231-238

Zgłobicki W, Baran-Zgłobicka B (2013) Geomorphological heritage as a tourist attraction. A case study in Lubelskie Province, SE Poland. Geoheritage 5:137-149. https://doi.org/10.1007/s12371-013-00766

Zouros N, McKeever P (2004) The European geoparks network. Episodes 27:165-171 